\title{
Competition overrides climate as trigger of growth decline in a mixed Fagaceae Mediterranean rear-edge forest
}

\author{
Álvaro Rubio-Cuadrado ${ }^{1}$ (D) J. Julio Camarero ${ }^{2} \cdot$ Guillermo G. Gordaliza ${ }^{1} \cdot$ Matteo Cerioni $^{2} \cdot$ Fernando Montes $^{3}$. \\ Luis Gil ${ }^{1}$
}

Received: 10 April 2020 / Accepted: 17 September 2020 / Published online: 1 October 2020

(C) INRAE and Springer-Verlag France SAS, part of Springer Nature 2020

\begin{abstract}
- Key message In recent decades, there has been a decline in growth in a rear-edge broadleaf forest of Fagus sylvatica, Quercus petraea, and Quercus pyrenaica. Although temperatures have been rising due to climate change, the observed decline in growth was mainly attributed to increased density and competition between trees since the cessation of traditional uses such as logging in the 1960s.

- Context In recent decades, two major factors have influenced tree growth in many forests: climate warming, which is associated with aridification and negative growth trends in many Mediterranean forests, and abandonment of forest management, resulting from forest policy in conjunction with rural depopulation in Europe, often leading to an increase in competition and a decrease in growth. - Aims Here, we study the growth trends in a mixed forest of Fagus sylvatica, Quercus petraea, and Quercus pyrenaica, where the abandonment of traditional uses in the 1960s has been followed by an increase in tree density. In this forest, both $F$. sylvatica and $Q$. petraea reach their south-westernmost limits of distribution.

- Methods Using dendrochronological methods and growth modeling, we assess the importance of climate warming on the shifts in competitive growth advantage of these three coexisting tree species and the relative importance of climate and competition on growth trends.

- Results Q. petraea and especially F. sylvatica showed a favorable evolution of their competitive capacity, despite the increase in temperatures that has occurred in the area in recent decades. $F$. sylvatica presented the lowest sensitivity to climate.

- Conclusion Under the current climate and forest structure conditions, competition is the most limiting factor on tree growth for the two oak species.
\end{abstract}

Keywords Dendroecology $\cdot$ Forest dynamics $\cdot$ Competitive advantage $\cdot$ Growth trend $\cdot$ Succession $\cdot$ Rear edge

Handling Editor: Andreas Bolte

Contribution of the co-authors Conceptualization: ARC. Methodology: ARC and FM. Software: FM. Formal Analysis: ARC. Investigation: ARC, JJC, GGG, and MC. Resources: JJC and LG. Data Curation: GGG. Writing - original draft: ARC. Writing - review and editing: ARC, JJC, FM, and LG. Visualization: ARC. Supervision: JJC, FM, and LG. Project Administration: LG. Funding acquisition: LG.

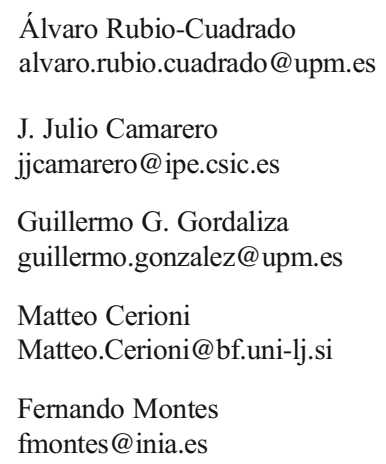

Luis Gil

luis.gil@upm.es

1 Departamento de Sistemas y Recursos Naturales, Escuela Técnica Superior de Ingeniería de Montes, Forestal y del Medio Natural, Universidad Politécnica de Madrid, Ciudad Universitaria s $/ \mathrm{n}$, 28040 Madrid, Spain

2 Instituto Pirenaico de Ecología (IPE-CSIC), Avda. Montañana 1005, 50080 Zaragoza, Spain

3 INIA-CIFOR, Ctra. de la Coruña km 7.5, 28040 Madrid, Spain 


\section{Introduction}

The last 30-year period has been the warmest on the Earth's surface since 1850 (IPCC 2014). The Mediterranean region has been severely affected by this warming, which has brought about aridification of extensive drought-prone areas (Jacob et al. 2014). Climate change will particularly affect temperate and Mediterranean forests located at the equatorial limit (rear edge) of the tree species distribution (Hampe and Petit 2005). This is the case of certain hardwood tree species (oaks, beech) which form mixed forests in mountain areas of Spain under a typical sub-Mediterranean influence (RubioCuadrado et al. 2018c), characterized by warmer and drier conditions in summer (Giorgi and Lionello 2008).

Climate change is already affecting forest growth and productivity (Reyer et al. 2014). Negative growth trends associated with climate warming have previously been described in several Mediterranean conifer forests (Macias et al. 2006; Sarris et al. 2007, 2011; Gea-Izquierdo et al. 2014; Camarero et al. 2015), but temperate oak and beech forests with recurrent summer droughts typical of the Mediterranean climate are also negatively impacted (Piovesan et al. 2008; Colangelo et al. 2017; Dorado-Liñán et al. 2017a). These negative growth trends are forecasted to increase over the course of the twenty-first century (Sánchez-Salguero et al. 2017). Indeed, the Iberian Peninsula has been described as the most sensitive region, and that which is most likely to suffer the largest decreases in forest productivity throughout the continent (Morales et al. 2007; Reyer et al. 2014).

It is unclear how mixed forests subjected to summer drought will be able to cope with the negative effects on growth of warmer and drier climate conditions. On the one hand, species mixing may improve the capacity of the forest to recover after disturbances (i.e., larger resilience; Pretzsch et al. 2013). This is due to resource use efficiency, which should enhance tree growth and stand productivity as a result of niche complementarity and facilitation between coexisting tree species (Richards et al. 2010). On the other hand, climate warming may favor species which are more adapted to drier and warmer conditions over typical temperate species (RubioCuadrado et al. 2018b).

In addition to climate change, land use changes have also affected growth trends in European forests (Linares et al. 2009; Camarero et al. 2011). In recent decades, forest policy in Europe has moved towards minimal intervention or nonmanagement for several different reasons: aiming to increase adaptability and resilience (Brang et al. 2014), for conservation purposes or due to the low economic value of forest resources (Moreno-Fernández et al. 2016). However, most European forests have a long history of anthropogenic transformations (Valbuena-Carabaña et al. 2010; Schoolman et al. 2018 ) and are composed of relatively young stands. In addition, during recent decades, forests have expanded into new areas, especially in Europe, mainly due to land use changes and afforestations, as well as to climate warming, all these new woodlands also being at early successional stages (Álvarez-Martínez et al. 2014; Penniston and Lundberg 2014; Price et al. 2017). Climate and land use changes have increased the frequency of disturbances (e.g., forest fires), thus preventing forests from reaching the latter serial stages (McLauchlan et al. 2020). In all these stands, natural dynamics has often led to an increase in tree density and tree-to-tree competition over recent decades, which can result in decreased tree growth (Voelker et al. 2008; Linares et al. 2010; Ruiz-Benito et al. 2013; Hosseini et al. 2018).

In this study, we analyze the growth trends in a mixed beech-oak forest ("El Hayedo de Montejo"; Fig. 1) dominated by Fagus sylvatica L., Quercus petraea (Matt.) Liebl., and Quercus pyrenaica Willd., with a long history of anthropogenic intervention (Pardo and Gil 2005). The studied forest harbors one of the southernmost (rear edge) and westernmost populations of $F$. sylvatica and Q. petraea in Europe, while in the case of $Q$. pyrenaica, it is the core of its distribution range (Pardo et al. 2004). Since the 1960s, traditional uses (logging, grazing) have ceased in the study area, and this has promoted forest recruitment and densification, evolving from open woodland to a dense forest (Gil et al. 2009). Previous studies conducted at this site have shown a general decline in growth of the dominant trees, attributed to temperature increase over recent decades (Dorado-Liñán et al. 2017a). The effect of competition on dominant trees is often neglected in dendroecological analyses, but substantial increases in density may reduce the resources available not only to dominated or suppressed trees but also to dominant trees, leading to growth decline. However, the complexity involved in disentangling the combined effects of climate change and the recent evolution of the forest, in particular the increase in competition, has meant that this situation has not yet been analyzed. The aim of this study is to evaluate the relative importance of climate and competition on the radial growth of dominant and codominant trees. Our specific objectives are as follows: (1) to study the evolution of the competitive growth advantage of the three coexisting species and (2) to analyze the relative importance of climate and competition on the radial growth of $F$. sylvatica, $Q$. petraea, and $Q$. pyrenaica in this mixed forest. We hypothesize that (1) the increase in temperature and frequency of drought events have a positive effect on the growth of the Mediterranean species (Q. pyrenaica) but have a negative impact on that of the temperate species (F. sylvatica and $Q$. petraea), (2) increase in competition has been the main limiting factor on the growth of the three species over recent decades, and (3) competition has a greater impact on $Q$. pyrenaica and $Q$. petraea than on the more competitive $F$. sylvatica. To fulfill the objectives and verify the hypothesis, we analyzed the relationships between climate, the tree-ring widths of the three species, and stand basal area. In order to 
evaluate the first hypothesis, we used climate-growth correlations and pointer year analysis. To evaluate the first and third hypotheses, the differences among the species, in terms of the long-term growth response to the evolution of site conditions, were analyzed using the competitive advantage index based on radial growth data (Rubio-Cuadrado et al. 2018b). Finally, to evaluate the second and third hypotheses, we analyzed the relative importance of competition and climate on basal area increment for the three species using mixed models.

\section{Materials and methods}

\subsection{Study area}

The study site, "El Hayedo de Montejo," is a mixed forest of 125 ha located in the Sistema Central mountain range, Central Spain $\left(41^{\circ} 07^{\prime} \mathrm{N} ; 3^{\circ} 30^{\prime} \mathrm{W}\right.$; Fig. 1), between 1250 and $1500 \mathrm{~m}$ a.s.l. The dominant species are Fagus sylvatica L. (hereafter beech), Quercus petraea (Matt.) Liebl. (hereafter oak), and the Mediterranean Quercus pyrenaica Willd., with a relative basal area of $27 \%, 23 \%$, and $50 \%$ and a mean diameter at breast height of 16.5, 19.9, and $24.1 \mathrm{~cm}$, respectively. This forest is close to the southernmost European distribution limit of the two temperate species (beech and oak). The beech and $Q$. petraea trees in the studied forest come from natural seeding, as do most of the $Q$. pyrenaica individuals, in contrast to coppice stands, which characterize $Q$. pyrenaica in Central Spain (Valbuena-Carabaña et al. 2008). The forest has historically been exploited for firewood and cattle grazing, which originated an open woodland structure of dispersed large, mature trees with scarce tree recruitment. However, for conservation purposes, cattle grazing has been forbidden in the forest since 1961, and the last logging operation was carried out in 1962 (López Santalla et al. 2003; Gil et al. 2009), favoring the increase in tree density and competition. In this regard, the inventories carried out in the forest in 1994, 2005, and 2015 (see Section 2.3 "Tree sampling and competition data") gave an average basal area for these years of $20.9,26.5$, and $28.8 \mathrm{~m}^{2} \mathrm{ha}^{-1}$, respectively, and an average density of 616,952 , and 910 trees ha ${ }^{-1}$, respectively.

The site has a Mediterranean continental climate with a 900-mm mean annual rainfall and a prolonged dry period during July and August (Gil et al. 2009). The mean annual temperature is around $9.5^{\circ} \mathrm{C}$ (climate data from the meteorological station of the "Natural Systems and Forest History" research group of the Universidad Politécnica de Madrid, located within the studied forest). The soil is classified as humic cambisol (Pardo et al. 1997), and the A horizon reaches an average depth of $50 \mathrm{~cm}$ which allows water to be stored during dry periods.

\subsection{Climate data}

Local climate data from the "Pantano El Vado" weather station $\left(41^{\circ} 0^{\prime} 13^{\prime \prime} \mathrm{N}\right.$ and $3^{\circ} 18^{\prime} 7^{\prime \prime} \mathrm{W}, 910 \mathrm{~m}$ a.s.l., AEMET, Spanish Meteorological Agency) located at ca. $21 \mathrm{~km}$ from the forest was used in this study. Missing monthly temperature and precipitation data as well as daily temperature data were estimated using linear regressions, which relate climatic variables from this station with the temperatures from "Puerto de Navacerrada" weather station (AEMET, $40^{\circ} 47^{\prime} 35^{\prime \prime} \mathrm{N}$ and $4^{\circ}$ $0^{\prime} 38^{\prime \prime} \mathrm{W}, 1894 \mathrm{~m}$ a.s.1.) and with precipitation data from "Arbancón" weather station (AEMET, 40 58 $0^{\circ}$ " $\mathrm{N}$ and $3^{\circ}$ 6" 57" W, $902 \mathrm{~m}$ a.s.l.) as follows:

$$
\begin{aligned}
& \mathrm{MT}_{\text {Pantano El Vado }}=0.9786 * \mathrm{MT}_{\text {Puerto de Navacerrada }}+5.8616 \\
& \mathrm{DT}_{\text {Pantano El Vado }}=0.847 * \mathrm{DT}_{\text {Puerto de Navacerrada }}+6.7033 \\
& \mathrm{MP}_{\text {Pantano El Vado }}=1.2395 * \mathrm{MP}_{\text {Arbancon }}+3.9396
\end{aligned}
$$

where MT, MP, and DT and are the monthly data for temperature and precipitation and the daily data for temperatures, respectively. $R^{2}=0.96$ for eq. $1, R^{2}=0.83$ for eq. 2 and $R^{2}$ $=0.76$ for eq. 3 . For the missing daily precipitation data from the "Pantano El Vado" local station, we used the daily data from "Arbancón" weather station (directly, without transforming) due to the low $R^{2}(0.13)$ regression line that relates both data series given the high spatial variability intrinsic to this variable.

In addition, to assess drought intensity, we used the Standardised Precipitation-Evapotranspiration Index (SPEI) (Vicente-Serrano et al. 2010a, b) calculated from the same local data using the Thornthwaite equation to estimate potential evapotranspiration within the SPEI package in $R$ (Beguería and Vicente-Serrano 2017). The SPEI drought index considers the effect of temperature on evapotranspiration rates and the cumulative water deficit. High and low SPEI values correspond to wet and dry conditions, respectively. The period from the arrival of water input (precipitation) to availability of a given usable resource (water absorption by the roots) differs considerably. Thus, the time scale over which water deficits accumulate becomes extremely important to calculate the SPEI. For this reason, we used a range of time scales (from 1 to 20 months) during which the water deficit and surplus are accumulated (Vicente-Serrano et al. 2010b).

\subsection{Tree sampling and competition data}

Three forest inventories were carried out in 1994, 2005, and 2015 in the studied forest. In each inventory, 125 circular plots systematically distributed on a square grid of $100 \mathrm{~m} \times 100 \mathrm{~m}$ were established covering the entire forest area. Permanent plots have been established since 2005, so the plots in the 
Fig. 1 Map of the Iberian Peninsula with the distribution of Fagus sylvatica (blue color), Quercus petraea (red), and

Quercus pyrenaica (green). Areas where at least two of the three species are mixed are represented in yellow. Sources: species distribution cartography has been elaborated by INIA-CIFOR from Third National Forest Inventory (https://www.miteco.gob.es/es/ biodiversidad/servicios/bancodatos-naturaleza/informaciondisponible/ifn3.aspx), and Digital

Terrain Model has been

elaborated by (C) Instituto

Geográfico Nacional

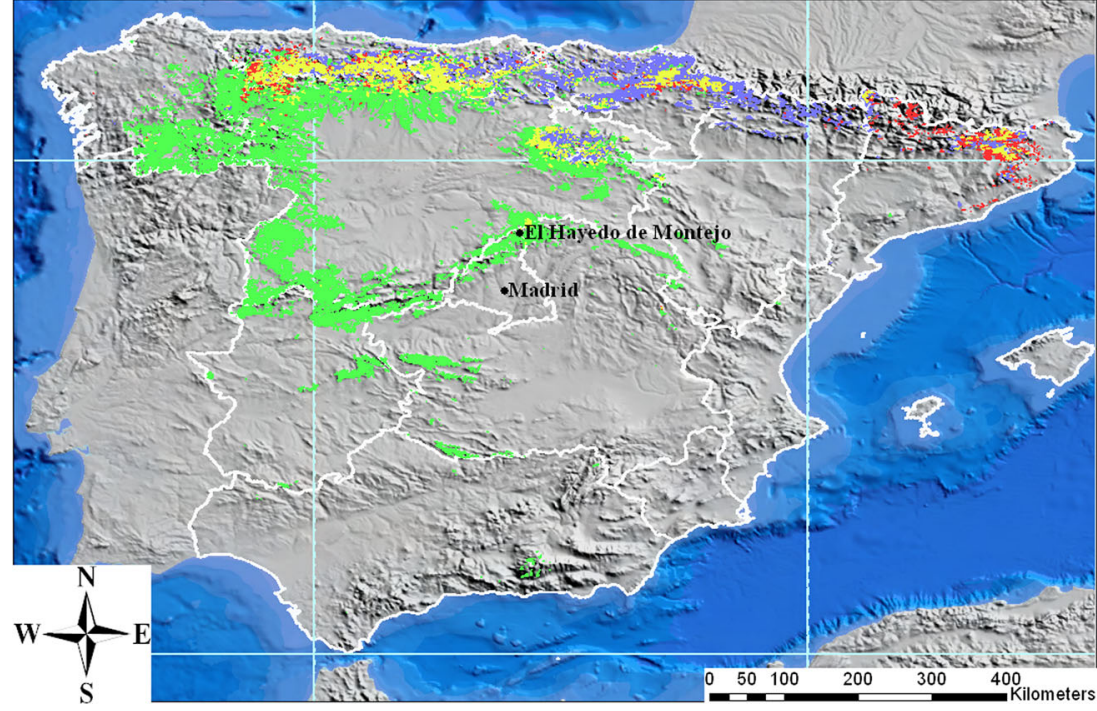

second and third inventories were at the same locations, whereas in 1994 the locations were different, although the area covered and the sampling intensity were the same. Based on the 2015 inventory data, all plots with mixed forest (presence of at least two of the three studied species) were selected for the extraction of two cores at $1.3 \mathrm{~m}$ (always perpendicular to the maximum slope) from a dominant or co-dominant tree of each species located nearest to the plot center using a Pressler increment borer. The diameter at breast height (DBH) of each tree bored was measured at $1.3 \mathrm{~m}$ with a caliper. Sampling took place during autumn of 2018. At least 20 trees per species, distributed across 32 plots, were sampled.

The total stand basal area (BA) and the fraction of it belonging to each of the species were calculated in 12.6$\mathrm{m}$ radius plots for the 1994, 2005, and 2015 inventories. The area of the plot with this radius is slightly larger than the crown projection of these species, in accordance with the DBH-crown diameter relationship of the Second Spanish National Forest Inventory (DGCONA 1998), so the BA estimated can be considered an indicator of stand level competition for resources. Spatio-temporal Universal Kriging (UK) was used to interpolate the total BA and spatio-temporal Ordinary Kriging (OK) to interpolate the proportion of each species for the 1994-2015 period from the BA measured in the inventory plots. As vegetation indices can indicate changes in stand density (Gómez et al. 2012), normalized difference vegetation index (NDVI) averaged from the available Landsat images for July-August of each year was used as an auxiliary variable in the UK interpolation of BA. These models interpolate the BA value and the proportion of each species at the plot locations for each year of the 1994-2015 period using the spatial and temporal autocorrelation of the variables to determine the optimal kriging weights. The low annual growth rates of the three analyzed species in the study area along with the species regeneration and development processes result in a high spatio-temporal autocorrelation of $\mathrm{BA}$ at the distance and time lags between measurements (100 m distant sampling plots and 10 years between inventories), providing consistent interpolated values for the 1994-2015 period. The spatio-temporal autocorrelation was modeled through the generalized product-sum variogram model (De Iaco et al. 2002). The OK variogram parameters were estimated using the weighted least squares (Cressie 1985), whereas the UK variogram parameters and mean function coefficients were estimated through the iteratively reweighted generalized least squares method proposed by Neuman and Jacobson (1984). Cross-validation was carried out to verify the unbiasedness of the estimated values and the ratio between the estimated kriging variance and the mean of the cross-validation squared residuals. Competition data are available in Rubio-Cuadrado et al. (2020).

\subsection{Radial growth data}

Cores of the sampled trees were mounted on wooden supports and carefully sanded until tree rings were clearly visible. After visual cross-dating, tree-ring widths (TRW) were measured to the nearest $0.01 \mathrm{~mm}$ using the semi-automatic LINTAB measuring device with the TSAP-Win software (RINNTECH, Heidelberg, Germany). Cross-dating was then further verified using the COFECHA program (Holmes 1997). A beech sample, with a very different age (129 years) and growth trend and very low correlation with the mean species series (close to 0 ), was discarded from further analysis. TRW data are available in Rubio-Cuadrado et al. (2020).

We calculated the mean growth series for each individual, and these series were subsequently transformed into basal area increments (BAI) as this variable is better than tree-ring width 
for capturing growth trends and accounting for the increase in size and age of stems (Biondi and Qeadan 2008). The BAI was calculated as follows:

$B A I=\pi\left(r_{t}^{2}-r_{t-1}^{2}\right)$

where $r_{t}$ and $r_{t-1}$ are the stem radii at the end and the beginning of a given annual ring increment corresponding to rings formed in $t$ and $t$-1 years, respectively.

When the cores did not contain the pith, the length of the missing radius was estimated to calculate the BAI as the distance to the geometric center of the tree, assuming concentric growth. Estimation was carried out by subtracting the corresponding cored length to the measured radius in the field, previously subtracting an estimated width of the bark. Bark thickness was estimated based on tree diameter using equations obtained from the data of the Second Spanish National Forest Inventory (DGCONA 1998). The functions used to estimate the bark thickness of $F$. sylvatica $\left(C_{F_{S}}\right), Q$. petraea $\left(C_{Q p e}\right)$, and $Q$. pyrenaica $\left(C_{Q p y}\right)$ are the following:

$C_{F s}=-0.00001 \mathrm{DBH}^{2}+0.0284 \mathrm{DBH}+0.3545$

$C_{Q p e}=1.4407 \mathrm{DBH}^{0.4071}$

$C_{Q p y}=7.4422 \ln (\mathrm{DBH})-23.845$

The final species chronologies were built by averaging all individual BAI measurements of the same species. The statistical quality of each chronology was checked via expressed population signal (EPS) (Table 1). The sample depth is considered adequate when EPS > 0.85 (Speer 2012).

Pointer years (years with anomalistically low BAI) are ecological indicators recording the reaction of the trees to environmental stress factors (Schweingruber et al. 1990). Based on previous studies (Rubio-Cuadrado et al. 2018a, 2018c; Nechita et al. 2019), negative pointer years were determined as those years in which at least $60 \%$ of the BAI series of one species showed a decrease in BAI of at least $40 \%$ relative to the average BAI in the 4 preceding years. The growth response to these unfavorable years and the ability to recover pre-disturbance growth levels after the disturbance were estimated for the tree-ring series through the resistance $(R t)$ and resilience $(R s)$ indices (Lloret et al. 2011):

$R t=B A I_{i} / B A I_{i-4}$

$R s=B A I_{i+4} / B A I_{i-4}$

where $B A I_{i}$ is the BAI value of the $i$ year. These indices were calculated with 4-year pre- $(i-4)$ and post-disturbance $(i+4)$ periods using the pointRes package in $R$ (van der MaatenTheunissen et al. 2015).

\subsection{Climate-growth relationships}

Since the BAI may contain long-term trends due to nonclimate factors, i.e., competition, to determine the main climatic drivers of tree growth, we used ring-width indices (RWI), removing the biological trends of the raw tree-ring widths (TRW) for each species using the ARSTAN program (Holmes 1997). We used a double detrending procedure to remove long-term growth trends (Holmes et al. 1986). First, we fitted a negative exponential curve to the TRW to remove the age effect in the first years of the growth series because of the low competition associated with the open woodland conditions during the establishment period of the analyzed trees, and second, we fitted a 32-year cubic smoothing spline to remove the low-frequency stand dynamics signals. In order to retain climatically related autocorrelation in growth, part of this signal was reintroduced into the residual time series by applying a first-order autoregressive model. Pearson correlation coefficients were then calculated for that period with more than ten samples per species, i.e., for the period 19712015, between the RWI (mean series of the detrended TRW) of each tree species and temperature and precipitation grouped on a daily or, alternatively, monthly basis. We tested the Pearson correlations between RWI and all possible climate
Table 1 Description of dendrochronological variables of cored trees

\begin{tabular}{llll}
\hline & F. sylvatica & Q. petraea & Q. pyrenaica \\
\hline No. of cored trees & 20 & 22 & 20 \\
Mean DBH (cm) & $28.6(1.0)$ & $32.8(1.3)$ & $33.6(2.5)$ \\
Mean/maximum length of series (years) & $45(1) / 56$ & $45(1) / 59$ & $64(7) / 143$ \\
Mean tree-ring width (mm) & $2.51(0.04)$ & $2.74(0.04)$ & $1.77(0.03)$ \\
Mean basal area increment $\left(\mathrm{cm}^{2}\right)$ & $10.6(0.3)$ & $13.4(0.3)$ & $10.5(0.2)$ \\
Mean basal area increment since 1971 $\left(\mathrm{cm}^{2}\right)$ & $11.7(0.3)$ & $15.4(0.3)$ & $10.6(0.2)$ \\
Mean correlation between trees & 0.34 & 0.29 & 0.17 \\
Expressed population signal since 1971 & 0.95 & 0.94 & 0.88 \\
\hline
\end{tabular}

Statistics were calculated for the maximum series length for each species. Standard errors are shown in parentheses 
window widths (periods of year) at daily resolution using the dendroTools package in $R$ (Jevšenak and Levanič 2018). We summarize the climate variables in the selected time window, using mean and sum for temperature and precipitation, respectively. We fixed a 30-day threshold as the minimum widths of the climate window in order to reduce the total number of calculated correlations and therefore the probability of obtaining spurious correlations. Correlation coefficients between RWI and monthly temperature and precipitation were calculated from June of the previous year to November of the growth year considering that the (i) climate during the previous year affects growth during the following year (Fritts 1976) and (ii) growth in the two Quercus species can occur until November (Pérez-de-Lis et al. 2017). Pearson correlations were also calculated between the detrended growth series and the SPEI using time scales from 1 to 20 months (see Section 2.2 "Climate data").

\subsection{Retrospective analyses of species competitive dynamics}

To study the specific signals of growth patterns of the three studied species and to analyze their differences, we used the competitive advantage index (CA) based on radial growth data (Rubio-Cuadrado et al. 2018b). This was based on the assumption that for trees of the same species growing in similar conditions of soil, competition, etc., higher growth values imply higher competitive ability (Weber et al. 2008). The CA index was used to compare the percentage of trees of two species showing increasing growth in 5-year intervals. In this way, we are able to study changes in the growth trends (due to climate or other factors) that benefit some species over others. Indeed, a species that maintains a constant downward trend in its relative growth will end up being dominated, benefiting the other competing species. However, this index does not consider other aspects of species competitiveness, such as resprouting capacity, carbon storage, seed dispersion capacity, and shade tolerance.

In order to obtain the CA index, firstly, the BAI series of all trees were smoothed, calculating them for 5-year moving intervals since we were interested in the long-term growth trends. Secondly, the number of ascending increments of BAI between consecutive years was summarized for each species. This was then transformed to percentages for species and year (i.e., percentage of trees of $F$. sylvatica, $Q$. petraea, and $Q$. pyrenaica with ascending increments in the 5-year BAI series between two consecutive years) to give a relative series of competitive ability over time. To calculate the competitive advantage series of $F$. sylvatica over $Q$. petraea $\left(\mathrm{CA}_{\mathrm{Fsyl}-\mathrm{Qpet}}\right)$, the percentage series of competitive ability for $Q$. petraea was subtracted from the percentage series of competitive ability for $F$. sylvatica. In the resulting competitive advantage series, positive values indicate competitive advantage for $F$. sylvatica, whereas negative values indicate competitive advantage for $Q$. petraea (Rubio-Cuadrado et al. 2018b). Competitive advantage series for $F$. sylvatica over Q. pyrenaica $\left(\mathrm{CA}_{\mathrm{Fsyl}-\mathrm{Qpyr}}\right)$ and for $Q$. petraea over Q. pyrenaica $\left(\mathrm{CA}_{\mathrm{Qpet}-\mathrm{Qpyr}}\right)$ were calculated in the same way.

To calculate the relationships between $\mathrm{CA}_{\text {Fsyl-Qpet }}, \mathrm{CA}_{\text {Fsyl- }}$ Qpyr, CA $A_{Q p e t-Q p y r}$, and climate, annual series of monthly temperature and precipitation were smoothed using a 5-year moving average. Pearson correlation coefficients between the CA and the smoothed series of climate variables from June of the previous year to November of the growth year were calculated. To calculate the $P$ values of these correlations, we corrected the degrees of freedom, which decrease due to the repeated use of the same data in the moving-average series (Munshi 2016). We also grouped monthly climatic data into seasons to better reflect the relationships between competitive advantage and seasonal climate conditions. The correlations between the CA series and the climatic variables series were analyzed between 1971 and 2015.

\subsection{Factors influencing the radial growth of tree species}

We used linear mixed-effects models to evaluate BAI trends of $F$. sylvatica, $Q$. petraea, and $Q$. pyrenaica with the following variables included in the saturated models as predictors or fixed factors: DBH of the cored tree at the year of each annual radial growth (annual DBH), as most of the growth variance is explained by tree size (Monserud and Sterba 1996; Cescatti and Piutti 1998; Diaconu et al. 2015); total plot basal area (BA) and the fraction of it belonging to each of the species at the year of each annual radial growth (kriging estimates of annual values at the sampling points), to study the influence of the competition; and the monthly climate variables showing significant correlations with growth for each species (temperatures of March of the current growth year and precipitations from June to October of the previous year and of April of the current year in the F. sylvatica model; temperatures from June to July of the current year and precipitations from July to September of the previous year and from April to July of the current year in the Q. petraea model, and temperatures of November of the previous year and June of the current year and precipitations from July to September of the previous year and from April to July of the current year in the Q. pyrenaica model). Instead of the previous monthly climate variables, we have also tried to introduce, as fixed effects, the temperature and precipitation periods that best correlates with growth for each species using daily resolution (Table 2); however, the resulting models explained less (in the case of $F$. sylvatica) or similar (in $Q$. petraea 
Table 2 Optimal climate windows (window width with the maximum correlation), window lengths in days, Pearson correlation coefficients, and associated probability levels $(P)$ calculated between the ring-width indices (RWI) and climate variables

\begin{tabular}{llllll}
\hline Species & Variable & Climate window & Days & Correlation & $P$ value \\
\hline F. sylvatica & Temperature & September 29-October 28 & 30 & -0.338 & 0.019 \\
F. sylvatica & Precipitation & April 04-May 05 & 32 & 0.327 & 0.023 \\
Q. petraea & Temperature & June 11-July 17 & 37 & -0.365 & 0.011 \\
Q. petraea & Precipitation & April 04-September 16 & 166 & 0.453 & 0.001 \\
Q. pyrenaica & Temperature & March 17-April 15 & 30 & -0.355 & 0.013 \\
Q. pyrenaica & Precipitation & May 13-September 11 & 122 & 0.408 & 0.004 \\
\hline
\end{tabular}

Temperature and precipitation variables are the averaged and total values of the grouped days, respectively and $Q$. pyrenaica) variability so to avoid mixing climate data with different temporal resolutions, only the monthly climate data were used in the final models. Only tree identity was considered a random component of the models (1|Tree). We considered all the period with available competition and growth data (1994-2015).

To predict BAI we adjusted the following linear mixedeffects model with random intercept and fixed slope:

$y_{i j}=\alpha+a_{j}+\beta z_{i j}+\varepsilon_{i j}$

where $y_{i j}$ represents $\log (\mathrm{BAI}+1)$ for year $i$ and tree $j, \alpha$ is the general intercept, $a_{j}$ is the random intercept (tree identity), $\beta$ is the vector of general slopes, $z_{i j}$ is the vector of fixed effects, and $\varepsilon_{i j}$ is the error with a first-order temporal autocorrelation (AR(1)) structure. We used logtransformed $(\mathrm{BAI}+1)$ data because BAI had a Gamma distribution. The distribution was tested using the Kolmogorov-Smirnov test.

To identify the best-supported model, we constructed all possible combinations of alternative models from the full model considering fixed and random effects and the interactions between the fixed effects. As the restricted maximum likelihood method (REML) estimates an unbiased variance, but does not allow models to be compared by minimizing the Akaike Information Criterion (AIC), we first fitted all possible models using the maximum likelihood method (ML) and then selected the best model by minimizing AIC and finally fitted it again using the restricted maximum likelihood method (REML) (Zuur et al. 2009). The use of the AIC was considered equivalent to using cross-validations to validate mixedeffects models (Fang 2011). The existence of multicollinearity among explanatory variables was evaluated by calculating the variance inflation factor (VIF). VIF values greater than 10 mean that there is high collinearity among variables (Dormann et al. 2013). The percentages of variance explained by fixed $\left(R_{m}^{2}\right.$, marginal $\left.R^{2}\right)$ and fixed plus random $\left(R_{c}^{2}\right.$, conditional $R^{2}$ ) factors were obtained following Nakagawa and Schielzeth (2013).

To study the effect of each variable on tree growth, we used the linear mixed-effects model fitted for each species to predict the evolution of the BAI according to the variation of each variable separately and fixing (as constants) the rest.

\section{Results}

\subsection{Climate trends}

The climate data did not show a significant trend when we considered the whole period. However, since 1976, there has been a significant $(p<0.01)$ temperature increase of +0.022 ${ }^{\circ} \mathrm{C} \mathrm{yr}^{-1}$ (Fig. 2).

\subsection{Growth trends}

The three studied species had two clearly differentiated periods according to their growth patterns: an ascending growth trend between 1971 and 1990 and a decreasing (in Q. petraea and more sharply in $Q$. prenaica) or stable ( $F$. sylvatica) growth trend from 1990 onwards (Fig. 3). The growth changes in $F$. sylvatica and $Q$. petraea were very similar over time, their growth curves being almost parallel. However, since 1995 , Q petraea growth has shown a slightly decreasing trend, while $F$. sylvatica has shown an increasing or stable growth trend, matching the growth of both species between 2007 and 2009, although this suddenly decrease in 2010 and notably since 2015 . The spline adjusted to the beech BAI decreases at the end of the period studied due to a sharp drop in growth caused by a spring frost in 2017, which severely damaged the leaves as they were unfolding.

\subsection{Climate-growth relationships}

The growth of $F$. sylvatica was directly related to the mean temperature of March of the current growth year $(r=0.29, P<$ 0.05 ) and to the total precipitation from June to October of the previous year $(r=0.32, P<0.05)$ (Fig. 4). Climate-growth correlations were similar in both Quercus species. Growth of the oak $(Q$. petraea) was inversely related to the mean temperature from June to July of the current growth year $(r=-$ $0.35, P<0.05)$ and directly related to the total precipitation 
Fig. 2 Climatic trends (annual mean temperature and total precipitation) in the study area (data of the "Pantano El Vado" AEMET station). The slopes of the simple regressions fitted to temperature (from 1976 to 2013) and precipitation (from 1943 to 2014), respectively, are shown

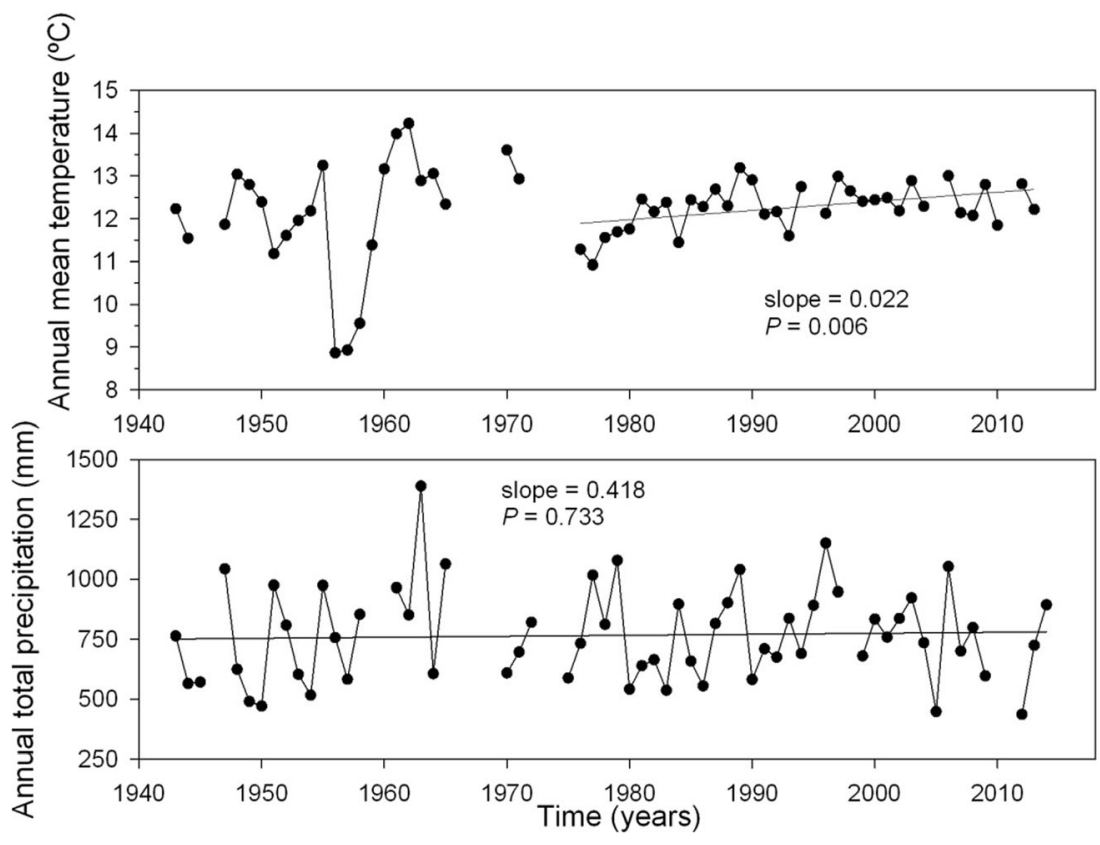

from July to September of the previous year $(r=0.43, P<$ $0.01)$ and from April to July of the current year $(r=0.50, P<$ $0.01)$. Similarly, the growth of $Q$. pyrenaica was directly related to the total precipitation from July to September of the previous year $(r=0.33, P<0.05)$ and from April to July of the current year $(r=0.44, P<0.01)$. Using a daily climate resolution, the periods that showed the greatest correlation with the growth of F. sylvatica were September 29October 28 for temperature and April 04-May 05 for precipitation (Table 2). In Q. petraea, the periods were June 11-July 17 for temperature and April 04-September 16 for precipitation, and in $Q$. pyrenaica, the periods were March
17-April 15 for temperature and May 13-September 11 for precipitation.

Only the Quercus species showed significant correlations with the SPEI drought index (Fig. 5). The highest correlations with SPEI corresponded to $Q$. pyrenaica. The growth of $Q$. petraea was negatively affected by the cumulative drought severity from March to October of the growth year, whereas the growth of $Q$. pyrenaica was affected by the cumulative drought severity from April to September.

F. sylvatica was the only species which presented pointer years, which were 1995 and 2017. Resistance was 0.45 and 0.18 for the years 1995 and 2017, respectively, and resilience
Fig. 3 Growth (BAI, basal area increment) of the three species studied since 1971 . We fitted a 30 -year-long cubic smoothing spline for each species to highlight BAI decadal to multidecadal variations. The rigidity of the splines was chosen visually. Note the sharp BAI drop in 2017 observed in beech due to a spring frost

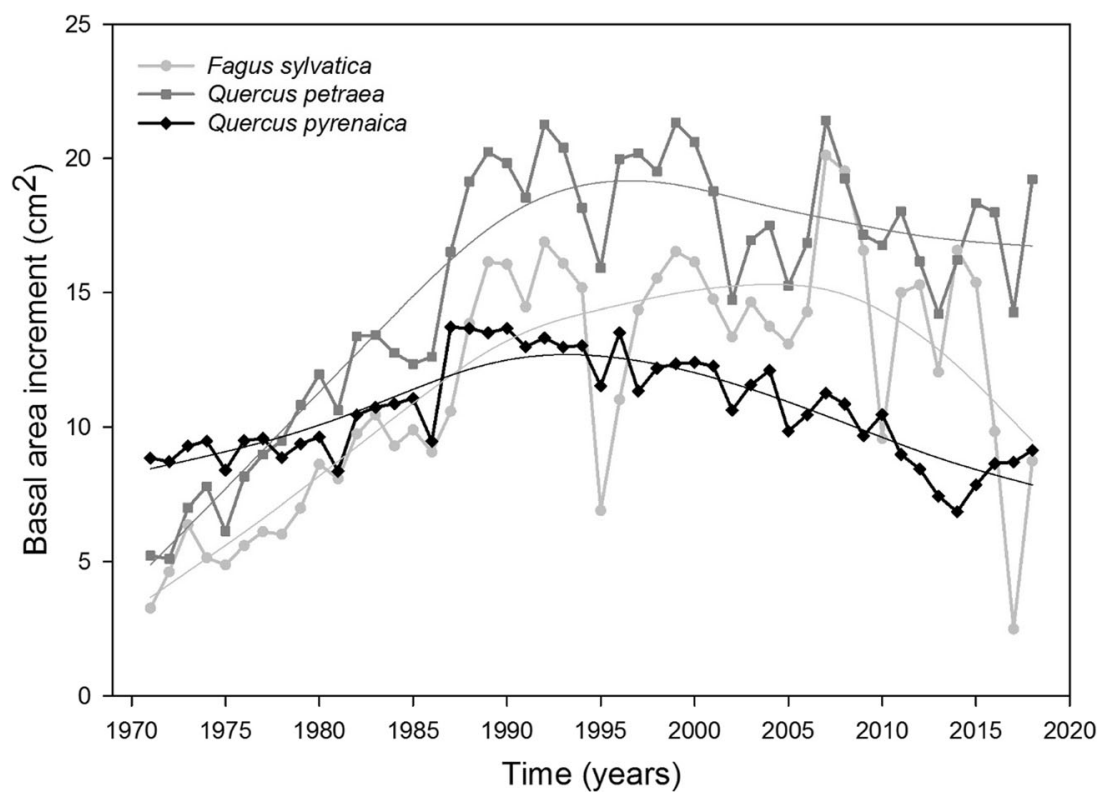


Fig. 4 Climate-growth relationships based on Pearson coefficients and calculated by relating ring-width indices (RWI) to monthly mean temperature and total precipitation. Months with lowercase letters correspond to the previous year. Horizontal dashed and dotted lines indicate significant correlations at $P<0.05$ and $P<0.01$, respectively
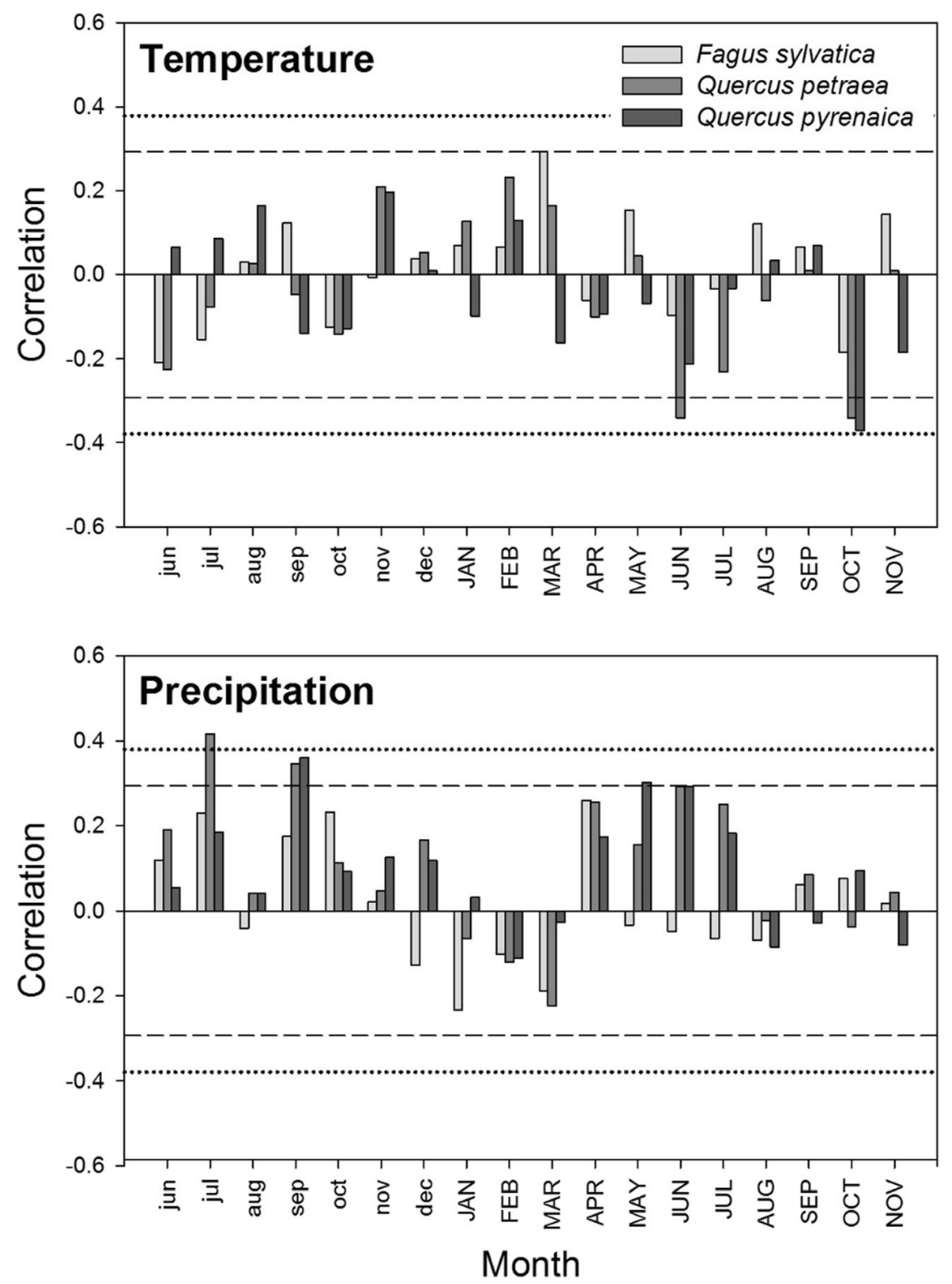

was 0.81 for the year 1995. The resilience for the year 2017 could not be calculated because we only had growth data up to the year 2018. There were spring frosts in both 1995 and 2017.

\subsection{Retrospective analyses of species competitive dynamics}

During the study period, there were alternating periods of competitive advantage for one or other of the studied species (Fig. 6). In general, we observed no clear trends of the competitive advantage series, except in recent years when the competitive advantage of $F$. sylvatica over both Quercus species $\left(\mathrm{CA}_{\text {Fsyl-Qpet }}\right.$ and $\left.\mathrm{CA}_{\text {Fsyl-Qpyr }}\right)$ showed a negative trend due to the effects of the spring frost of 2017. However, F. sylvatica showed an increasing growth for a higher percentage of trees than Q. petraea and Q. pyrenaica (i.e., $\mathrm{CA}_{\mathrm{Fsyl}-\mathrm{Qpet}}$ or $\mathrm{CA}_{\mathrm{Fsyl}-\mathrm{Qpyr}}>0$ ) in $67 \%$ and $65 \%$ of the years, respectively, with average values for the competitive advantage series of $5.5 \%\left(\mathrm{CA}_{\text {Fsyl-Qpet }}\right)$ and $10.8 \%\left(\mathrm{CA}_{\text {Fsyl-Qpyr }}\right)$. Although the percentage of trees of $Q$. petraea with increasing growth was only larger than that of $Q$. pyrenaica in half of the years, the average value of the $\mathrm{CA}_{\text {Qpet-Qpyr was }} 5.3 \%$.

Precipitation from May to June was inversely related with the competitive advantage of $F$. sylvatica over Q. petraea (Table 3 ). The temperature from June to July was also inversely related with the competitive advantage of $Q$. petraea over $Q$. pyrenaica, while precipitation of February and June was directly related with this advantage. There were no significant correlations of $\mathrm{CA}_{\text {Fsyl-Qpyr }}$ with the climate variables. 


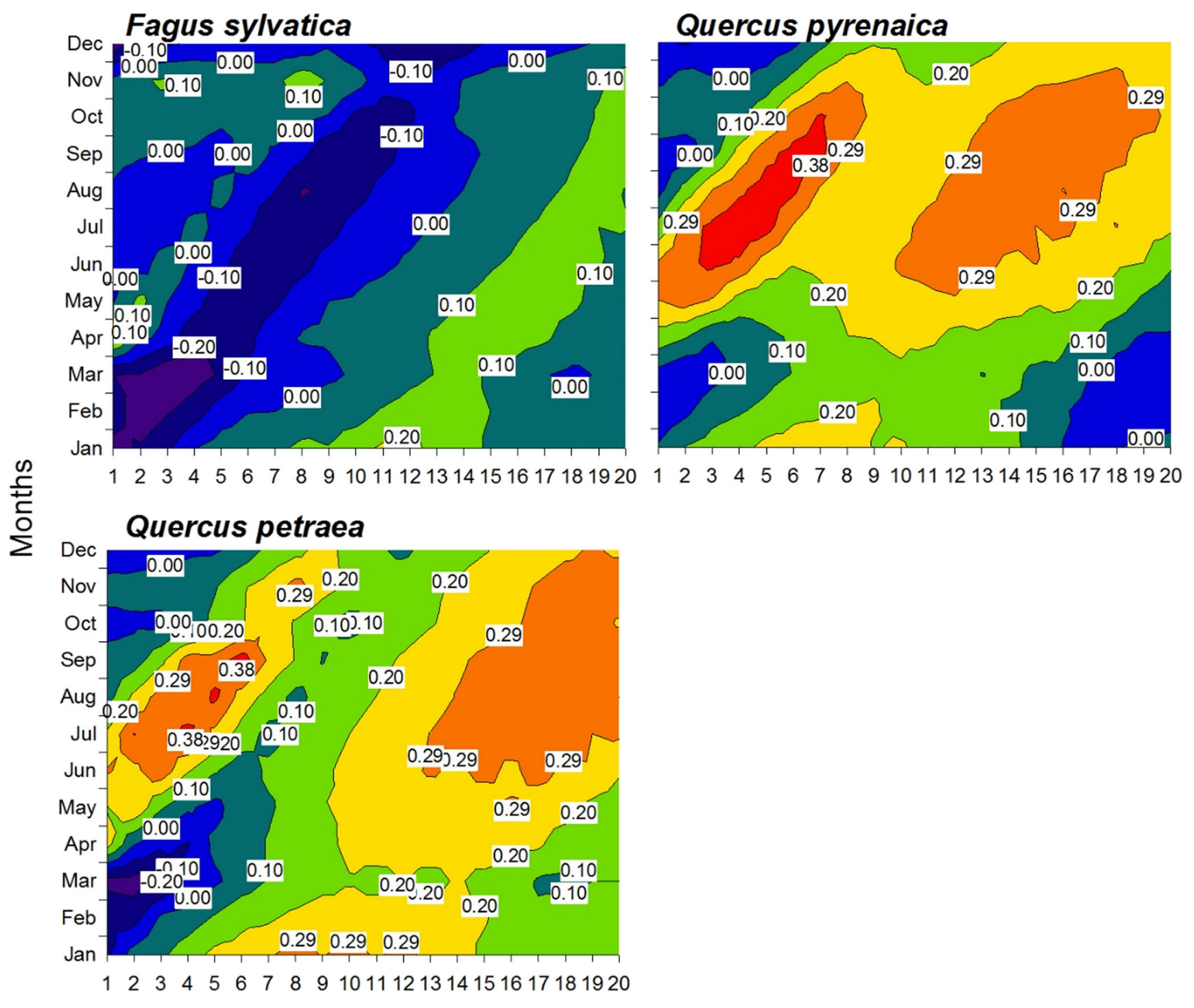

Time scale (months)

Fig. 5 Pearson correlations calculated between the ring-width indices (RWI) and the SPEI drought index from January to December ( $y$ axes) and for time scales between 1 and 20 months ( $x$ axes). Correlation values higher than 0.29 and 0.38 are significant at $P<0.05$ and 0.01 , respectively

\subsection{Factors influencing species growth trends}

In the three growth models (Table 4 and Fig. 7), the VIF of all predictors was lower than 3 , so collinearity was assumed to be low. According to these models, $38.8 \%$ (for $F$. sylvatica), $14.2 \%$ (for $Q$. petraea), and $12.1 \%$ (for $Q$. pyrenaica) of the BAI variability remained unexplained. Similarly, $30.7 \%$, $38.1 \%$, and $36.5 \%$ of the variability in each of these species, respectively, were explained by fixed factors $\left(R_{\mathrm{m}}^{2}\right)$, and $30.5 \%, 47.7 \%$, and $51.4 \%$ of the variability $\left(R_{\mathrm{c}}^{2}\right)$ were explained by differences between trees (soil, orientation, slope, altitude, genetics, vigor, etc.).

In the beech growth model, there was an interaction between April precipitation and mean March temperature.
According to this interaction, when one of the two variables had low values (low temperature or low precipitation), as the value of the other variable increased, growth also increased (Fig. 7). However, when one of the variables showed high values, the other variable had no significant effects (note the width of the confidence interval for this case).

The three BAI models presented a good fit, although in both Quercus models, the fitted BAI showed low inter-annual variability (Fig. 8a). Positive BAI trends of $F$. sylvatica and $Q$. petraea were explained by the increase in tree DBH (Fig. 8b). Climate variables explained the inter-annual BAI variability in the three studied species, the BAI decrease in F. sylvatica, and part of 

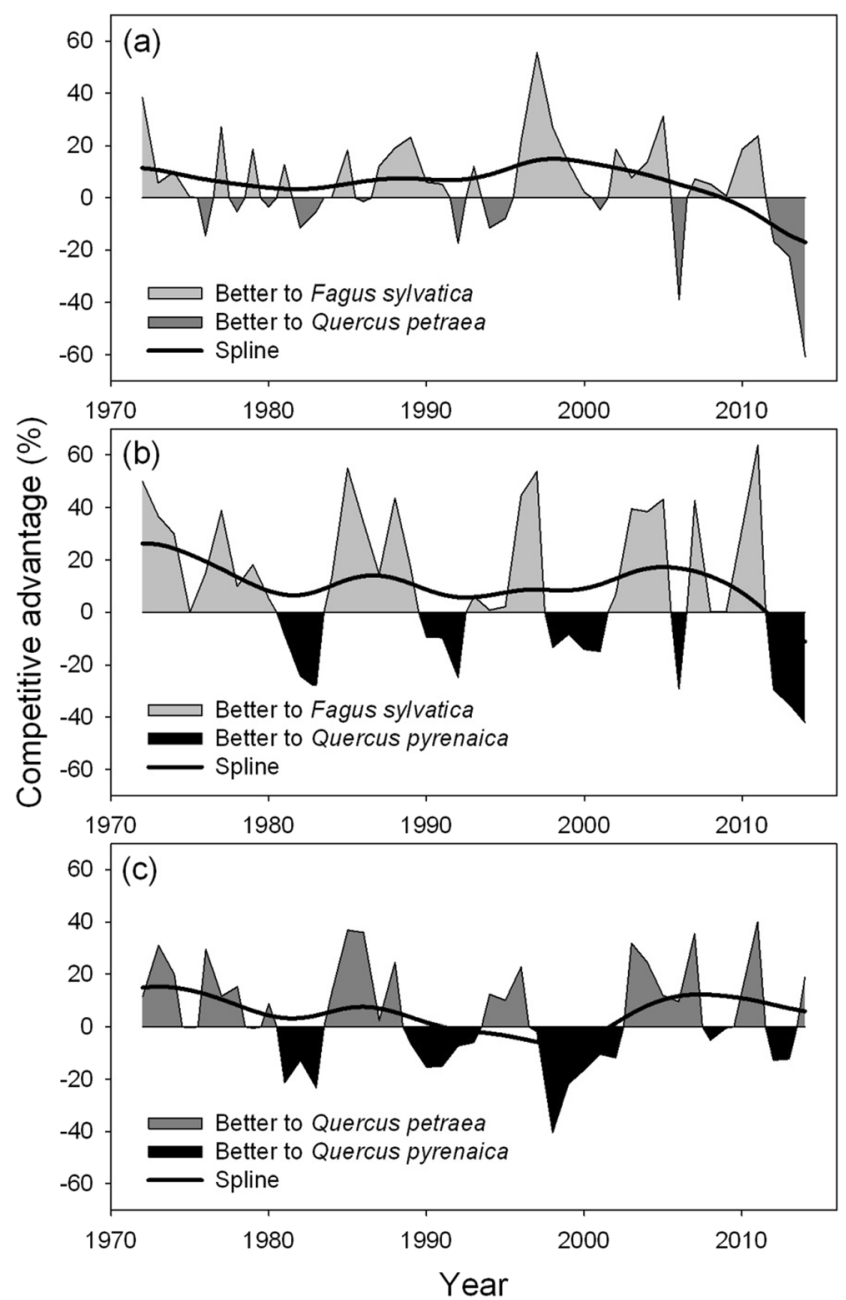

Fig. 6 Reconstructed competitive advantage (CA) series of Fagus sylvatica over Quercus petraea (a, $\mathrm{CA}_{\mathrm{Fsyl}-\mathrm{Qpet}}$ ), Fagus sylvatica over Quercus pyrenaica (b, $\mathrm{CA}_{\mathrm{Fsyl}-\mathrm{Qpyr}}$ ), and Quercus petraea over Quercus pyrenaica (c, $\mathrm{CA}_{\mathrm{Qpet}-\mathrm{Qpyr}}$ ) from 1971 to 2018 . We fitted a 30-year-long cubic smoothing spline for each CA to show the decadal to multi-decadal variations. The rigidity of the splines was visually chosen

the BAI decrease in $Q$. petraea. Finally, tree-to-tree competition explained most of the BAI decrease in $Q$. petraea and the BAI decrease observed in Q. pyrenaica.

Table 3 Pearson correlation coefficients and associated probability levels $(P)$ calculated between the different competitive advantage (CA) series and climate variables

\begin{tabular}{llll}
\hline CA & Climate variable & Correlation & $P$ value \\
\hline CA $_{\text {Fsyl-Qpet }}$ & Precipitation from May to June & -0.41 & $<0.05$ \\
CA $_{\text {Qpet-Qpyr }}$ & Temperature from June to July & -0.33 & $<0.10$ \\
& Precipitation February & 0.47 & $<0.05$ \\
& Precipitation June & 0.40 & $<0.05$ \\
\hline
\end{tabular}

Temperature and precipitation variables are the averaged and total values of the grouped months, respectively

\section{Discussion}

Contrary to expectations, we found that the increase in temperatures since the 1970s (Fig. 2) has not benefited the subMediterranean $Q$. pyrenaica over the temperate species Q. petraea and F. sylvatica. According to our results (Fig. 6), the competitive dynamics benefited $Q$. petraea and especially $F$. sylvatica, the growth rates of which are increasing with respect to the other species although $Q$. petraea currently displays a higher absolute growth (Fig. 3). This result can be partly explained by the increase in competition associated with the cessation of forest management, which has been a major factor behind the decline in growth of $Q$. petraea and Q. pyrenaica, i.e., they are being outcompeted by beech (Fig. $8 b$ ). This study reinforces the notion that the reduction in logging and grazing has been one of the main drivers of forest dynamics in Spain over recent decades (Hernández et al. 2019).

\subsection{Climate-growth relationships}

Despite the higher vulnerability of beech to extreme climate events such as drought and frost in comparison with both Quercus species (Aranda et al. 1996, 2000, 2005), beech growth was the least sensitive to mean climate conditions (Figs. 4 and 5 and Table 2). Unlike the findings of studies conducted in other temperate forests with Mediterranean influence (Piutti and Cescatti 1997; Rozas 2001) or those of previous studies focusing on aged trees of this forest (Dorado-Liñán et al. 2017a), high temperatures did not seem to be a limiting factor for beech growth. In fact, the only significant negative impact on growth that was identified occurred during the climate window on September 29-October 28 (Fig. 4 and Table 2), when radial growth was negligible or stopped (Martinez del Castillo et al. 2018). Similarly, site conditions did not seem to be especially limiting to beech growth. While many missing rings were detected in dominant beeches in other temperate forests located further north due to adverse climate conditions or suppression caused by intense competition (Rubio-Cuadrado et al. 2018c), no missing rings were detected in this case. These results agree with those of other recent studies which point to adaptation to drought in the most southerly beech forests (Tegel et al. 2014; Cavin and Jump 2017; Muffler et al. 2020).

The influence of precipitation from June to October of the previous year on beech growth (see Section 3.3 "Climategrowth relationships") is related to the amount of carbohydrates stored in the previous growing season and therefore available at the beginning of the current vegetative period (Bréda et al. 2006), whereas the influence of March temperature could be related to earlier breaking of winter dormancy along with enhanced stimulation of the cambium activity (Seidling et al. 2012). In this respect, beeches in the study area 
Table 4 Regression coefficients of the fixed effects (standard errors are shown in parentheses) and marginal $\left(R_{\mathrm{m}}^{2}\right)$ and conditional $R^{2}\left(R_{\mathrm{c}}^{2}\right)$ for the best linear mixed-effects models of basal area increment for $F$. sylvatica, Q. petraea, and Q. pyrenaica, considering the 1994-2015 period

\begin{tabular}{llll}
\hline & $F$. sylvatica & Q. petraea & Q. pyrenaica \\
\hline Intercept & $2.611(0.073)^{* * * *}$ & $2.821(0.094)^{* * * *}$ & $2.355(0.115)^{* * * *}$ \\
Annual DBH & $0.275(0.045)^{* * *}$ & $0.265(0.060)^{* * *}$ & \\
Annual BA & & $-0.298(0.095)^{* *}$ & $-0.453(0.077)^{* * *}$ \\
Fraction of $F$. sylvatica & & $-0.299(0.103)^{* * *}$ & $-0.464(0.141)^{* *}$ \\
Fraction of $Q$. petraea & & & $-0.366(0.134)^{* *}$ \\
Fraction of $Q$. pyrenaica & & $-0.306(0.108)^{* * *}$ & $-0.570(0.151)^{* * *}$ \\
$\mathrm{~T}_{\text {March }}$ & $0.078(0.016)^{* * *}$ & & \\
$\mathrm{P}_{\text {April }}$ & $0.064(0.018)^{* * *}$ & & \\
$\mathrm{P}_{\text {from previous June to previous October }}$ & $0.077(0.015)^{* * *}$ & & \\
$\mathrm{~T}_{\text {March }} \times \mathrm{P}$ April & $-0.100(0.027)^{* * *}$ & & $0.041(0.008)^{* * *}$ \\
$\mathrm{P}_{\text {from April to July }}$ & & $0.030(0.007)^{* * * *}$ & \\
$\mathrm{P}_{\text {from previous July to previous September }}$ & & $0.037(0.008)^{* * * *}$ & 0.365 \\
$R_{\mathrm{m}}^{2}$ & 0.307 & 0.381 & 0.879 \\
$R_{\mathrm{c}}^{2}$ & 0.612 & 0.858 & \\
\hline
\end{tabular}

Predictors were standardized previously to fit the models. Significance levels: $* * P<0.01$ and $* * * P<0.001$, respectively. " $\times$ " indicates interactions sprout at the end of April (Millerón et al. 2012). It is also worthy of note that the beech trees in this study were not sensitive to June precipitation, which has been shown to drive growth in this species in populations of northern Spain (Rozas et al. 2015), while the precipitation just before and at the beginning of the vegetative period was significant (Table 2). This may be explained by the fact that the phenology of these trees was more advanced in comparison with northern populations located in cool, wet sites. Finally, spring frosts cause noticeable growth losses in such populations (Dittmar et al. 2006). In the study area, four spring frosts have occurred in the

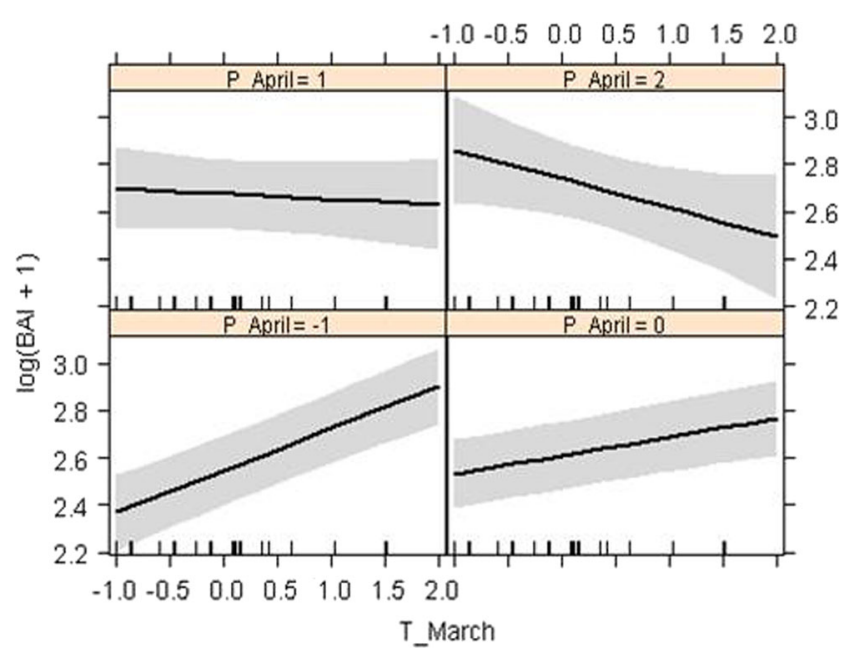

Fig. 7 Effects of interactions between climate variables (P April, April precipitation; T_March, mean March temperature) on radial growth (BAI, basal area increment) of beech according to the selected linear mixedeffects model. Factors are standardized. Shaded bands indicate the $95 \%$ confidence intervals. Positions of the data along the abscissa axis are denoted by tick marks last 25 years: 1995, 2010, 2013, and 2017 (data not shown). The years 1995 and 2017 were the pointer years, but sharp drops in the beech radial growth was found in all these years.

Radial growth of the two Quercus species was also related with the precipitation during the previous growing season, as well as with spring and summer precipitation of the growth year. In addition, the temperatures of June and July (see Section 3.3 "Climate-growth relationships"), when the highest radial growth occurs (assessed through band dendrometer measurements not shown in this paper), and those from mid-March to mid-April (Table 2), just before the beginning of the vegetative period, were inversely related with the total growth of $Q$. petraea and $Q$. pyrenaica, respectively, which may be due to their higher proportion of living parenchyma in sapwood and higher respiration values per unit volume of living parenchyma compared with $F$. sylvatica (Rodríguez-Calcerrada et al. 2015).

\subsection{Species competitive dynamics}

The BAI trends (Fig. 3) and the competitive advantage series (Fig. 6) are clearly linked: the higher growth increments (i.e., the higher slope of the splines in Fig. 3) of F. sylvatica and $Q$. petraea compared with $Q$. pyrenaica until 1990 led to large positive values, around $20 \%$, of $\mathrm{CA}_{\mathrm{Fsyl}-\mathrm{Qpyr}}$ and $\mathrm{CA}_{\mathrm{Qpet}-\mathrm{Qpyr}}$. From then on, there was a stabilization of $F$. sylvatica growth along with a decrease in growth in both Quercus species, and consequently, $\mathrm{CA}_{\text {Fsyl-Qpet }}$ and $\mathrm{CA}_{\text {Fsyl-Qpyr }}$ continued to maintain positive values, while $\mathrm{CA}_{\mathrm{Qpet}-\mathrm{Qpyr}}$ alternated between positive and negative values, although the positive values predominated due to the greater decreases in $Q$. pyrenaica growth. Finally, there was a sharp drop in $\mathrm{CA}_{\text {Fsyl-Qpet }}$ and $\mathrm{CA}_{\text {Fsyl-Qpyr }}$ due to damage suffered by beech in the late frost of 2017 . 
(a)

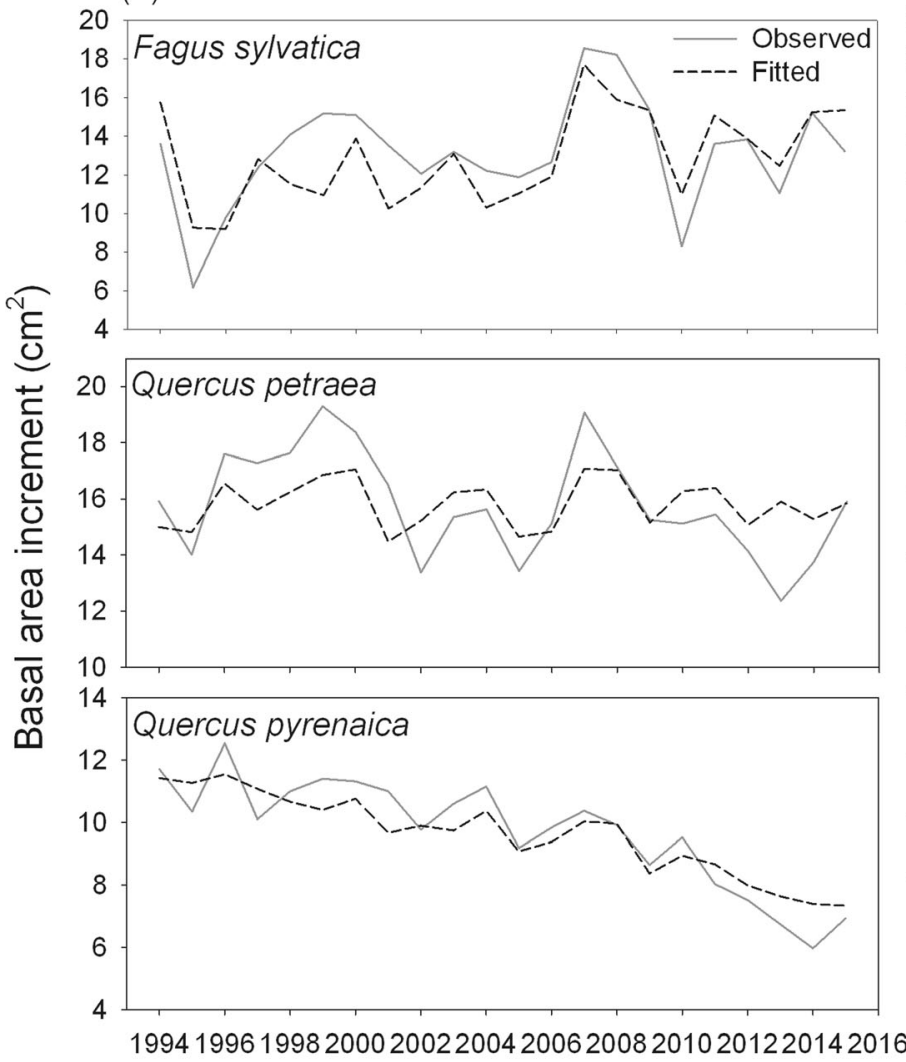

(b)
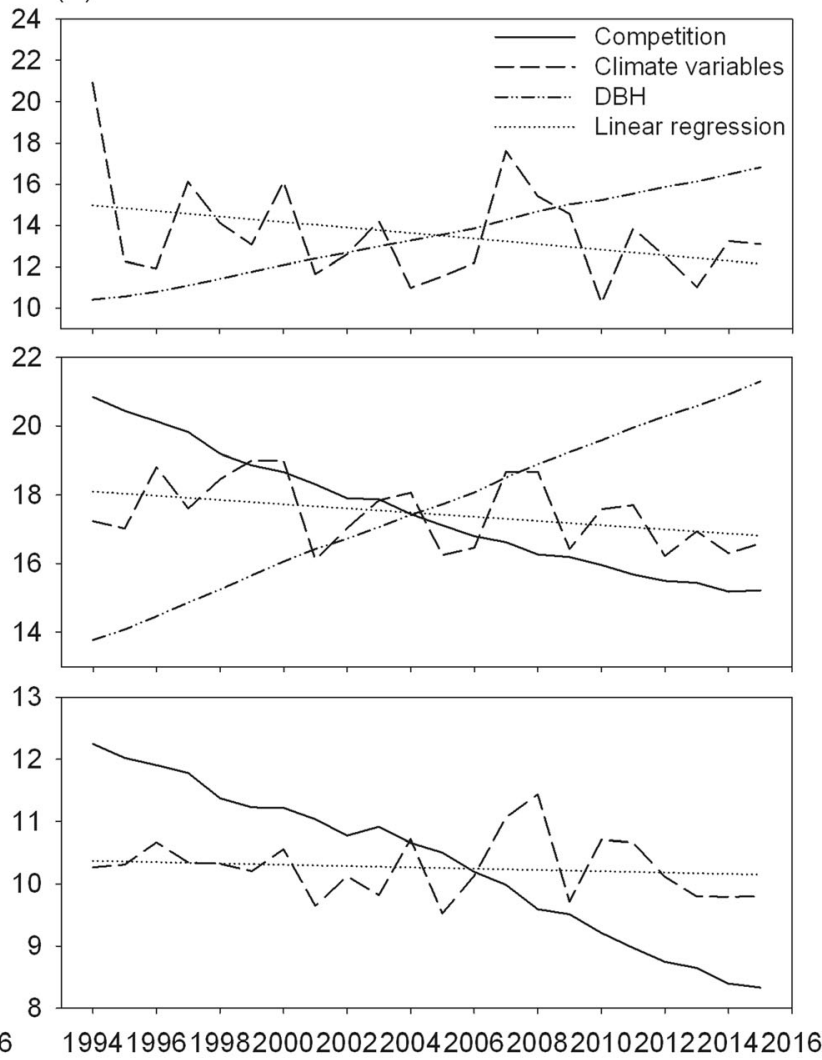

\section{Time (year)}

Fig. 8 Observed and predicted basal area increment (BAI) for Fagus sylvatica, Quercus petraea, and Quercus pyrenaica (a) and BAI prediction series for the variation, within the studied period, of tree diameter (DBH), competition (total BA and the fraction of it belonging to each of the species), and climatic effects separately, keeping the rest of the fixed

Most of the relationships between the competitive advantage series and climate (Table 3) can be explained by the different climate-growth relationships presented in Fig. 4, which are associated with differences in spatio-temporal use of water, cambium phenology (Michelot et al. 2012), and physiology (Aranda et al. 1996, 2005). While beech growth showed no relationship with precipitation from May to June, both Quercus species presented significant positive relationships. Thus, the precipitation in these months benefits the Quercus species over $F$. sylvatica. Similarly, $Q$. pyrenaica growth showed no relationship with summer temperatures, whereas $Q$. petraea presented significant inverse relationships. Consequently, high summer temperatures, along with low precipitation in February and June, will have a negative impact on $Q$. petraea against $Q$. pyrenaica. High precipitation in February may benefit $Q$. petraea growth to a greater extent than $Q$. pyrenaica because its radial growth starts earlier, as in similar Iberian temperate forests (Pérez-de-Lis et al. 2017),

In our hypothesis, we expected an improvement in the competitive capacity of the more drought resistant species, as previously reported in temperate forests of northern Spain effects constant (mean value of the period) (b). In the (b) plots, linear regressions were fitted to BAI predictions for the variation in climate variables (keeping $\mathrm{DBH}$ and $\mathrm{BA}$ constant) to show the long-term BAI trend but not considering annual variability

under mesic conditions (Rubio-Cuadrado et al. 2018b). However, in recent decades, the competitive advantage series has shown a tendency favoring temperate species, especially beech, despite the negative impact on beech growth of extreme climate events such as droughts (Rubio-Cuadrado et al. 2018c) and spring frosts (Dittmar et al. 2006). These results may be related to the lower sensitivity and greater resistance to drought shown by rear-edge beech populations compared with those situated at the core of the species range (Cavin and Jump 2017; Serra-Maluquer et al. 2019). This greater resistance may be explained by favorable local environmental factors (e.g., site topography, soil water holding capacity) or by acclimation to drought (RodriguezCalcerrada et al. 2010) through phenotypic plasticity or genotypic adaptation. In any case, recent studies have revealed high resilience to drought in beech saplings, which rapidly resume physiological activity after the dry period (Pflug et al. 2018). These aspects clearly merit further investigation to determine whether adult beech trees display similar resilience to different extreme climate events (droughts, frosts) in rear-edge populations. 


\subsection{Factors influencing species growth trends}

The model has been built for the period 1994-2015 as we do not know the precise evolution of the competition before the first forest inventory carried out in 1994. Although the time frame considered may be short, due to the relatively intensive use by cattle in the past and its subsequent abandonment, there has been a considerable increase in competition in this short period of time, which makes this forest an ideal site to study its effect on growth. The systematic sampling of trees performed, where all plots (of the inventory carried out in the studied forest in 2005) with mixed forest were sampled, and the high EPS values (Table 1) make our models representative of the growth dynamics of the dominant and co-dominant trees of the whole forest. However the short time frame considered together with low number of trees per species sampled limits the scope of the results. Further research studying longer periods of time and larger number of trees, and covering the distribution area of the species, are needed to know the factors that are influencing at a global level the growth trends of $F$. sylvatica, $Q$. petraea, and $Q$. pyrenaica.

As reported in other studies (Monserud and Sterba 1996; Cescatti and Piutti 1998; Diaconu et al. 2015), most or at least a large proportion of the tree growth in $F$. sylvatica and $Q$. petraea was explained by tree size (DBH; Table 4). In alternative models for $Q$. pyrenaica that included the DBH (results not shown), this variable also explained most of the radial growth variability, but was not significant because it had a very wide confidence interval. Both Quercus BAI models, especially the Q. pyrenaica model, were less sensitive to climate than the $F$. sylvatica model, as shown by the lower coefficients of the climate factors (Table 4), hence displayed lower inter-annual variability (Fig. 8a).

According to our BAI models (Table 4), the increase in competition following the cessation of forest management is the most important factor related with the negative growth trend of Q. petraea and $Q$. pyrenaica, although climate also explained some of the Q. petraea growth decline (Figs. 3 and 8b). These results are concordant with previous works, where highfrequency growth changes are related to climate, while radial growth is explained by the size and competition (SánchezSalguero et al. 2015; Liang et al. 2019). Indeed, competition among trees may cause much larger reductions in forest growth and carbon uptake than climate stress (Vayreda et al. 2012; Rozas 2014). The greater importance of competition rather than climate in explaining tree radial growth has also been reported in large-scale studies conducted both in temperate-boreal (Foster et al. 2016) and in water-limited ecosystems (Gómez-Aparicio et al. 2011). However, some studies give greater weight to the climate and global warming effect on growth trends, especially in Mediterranean rear-edge forests (Piovesan et al. 2008; Dorado-Liñán et al. 2017b; Charru et al. 2017; Dorado-Liñán et al. 2019), although these studies do not usually analyze the effect of the evolution of competition because it is uncommon that inventory data is available for a sufficiently long period of time. Our study shows the greater relative importance of competition in explaining radial growth not only in Mediterranean $Q$. pyrenaica but also in a rear-edge population of $Q$. petraea, providing further evidence of the complex relationships between climate and growth decline in some temperate forests at the equatorial range edge of their distribution (Tegel et al. 2014; Cavin and Jump 2017; Muffler et al. 2020). In fact, beech is currently expanding in Spain despite the reported aridification trends (Sánchez de Dios et al. 2016, 2020) due to its competitiveness, shade tolerance, and greater dispersion capacity (Harmer 1994; Millerón et al. 2013), which allows it to access the best situations in terms of soil depth and orientation. The competition was not significant in the $F$. sylvatica BAI model (Table 4), possibly due to its greater competitiveness in comparison with the oak species (Hein and Dhôte 2006; Manso et al. 2015). This could result in a negative influence of beech admixture on oak. However, according to the models obtained, the presence of $Q$. pyrenaica seems to be the most limiting for the growth of both Quercus, while the presence of $Q$. petraea was the least limiting. This result may be influenced by the larger average size of $Q$. pyrenaica trees (see Section 2.1 "Study area") and the direct relationship between size and competition (Stadt et al. 2007). Furthermore, previous studies have shown that competition for resources in unfavorable climatic years may be lessened in mixed beech-oak stands with respect to pure stands (del Río et al. 2014).

Changes in tree-to-tree competition must be considered in order to understand long-term changes in growth and forest dynamics since they may be more relevant than climate to forecast changes in forest composition and dynamics (Sánchez-Salguero et al. 2015). In addition, changes in competition can drive or modulate the responses of tree growth and functioning (e.g., water-use efficiency) to climate (Linares et al. 2010; Martín-Benito et al. 2011; Fernández-de-Uña et al. 2015; González de Andrés et al. 2018). The effect on tree growth of the increase in competition resulting from the abandonment or change in previous forest management practices (which is common in many European forests) and that of global warming can be difficult to unravel when analyzing the causes of growth decline. Therefore, by combining dendrochronological data with historical forest inventories, it is possible to provide estimates on the evolution of stand competition among trees over time and improve our knowledge on the causes of growth decline in some of the temperate rear-edge forests.

\section{Conclusions and management implications}

There has been an increase in temperatures in the study area from 1975 onwards. However, the rear-edge $Q$. petraea and especially $F$. sylvatica presented low sensitivity to climate and 
showed favorable evolution of their competitive capacity over the Mediterranean $Q$. pyrenaica. F. sylvatica also showed higher competitive capacity than $Q$. petraea throughout most of the studied period. Spring frosts, in the case of $F$. sylvatica, and increased competition resulting from the cessation of forest management, for the two Quercus species, were the most limiting factors to tree growth. Management strategies, such as selective thinning and promoting of sexual reproduction in Q. pyrenaica, should be considered a means to improve longterm growth and enhance the resilience of Quercus populations.

Acknowledgments We are grateful to Carlos Magro Hernández for her assistance during fieldwork.

Funding The study was funded by the Autonomous Community of Madrid through the project "BOSSANOVA" (P2013/MAE-2760), by the Spanish Ministry of Economy and Business through the projects "FORESTCHANGE" (AGL2016-76769-C2-1-R) and "Fundiver" (CGL2015-69186-C2-1-R) and through a FPU PhD fellowship (FPU15/03533) to ARC of the Spanish Ministry of Science, Innovation and Universities.

Data availability The datasets generated and/or analyzed during the current study are available in the e-cienciaDatos repository, https://doi.org/ 10.21950/VEQWPI.

\section{Compliance with ethical standards}

Conflict of interest The authors declare that they have no conflict of interest.

\section{References}

Álvarez-Martínez JM, Suárez-Seoane S, Stoorvogel JJ, de Luis CE (2014) Influence of land use and climate on recent forest expansion: a case study in the Eurosiberian-Mediterranean limit of north-west Spain. J Ecol 102:905-919. https://doi.org/10.1111/1365-2745. 12257

Aranda I, Gil L, Pardos J (1996) Seasonal water relations of three broadleaved species (Fagus sylvatica L., Quercus petraea (Mattuschka) liebl. and Quercus pyrenaica willd.) in a mixed stand in the centre of the Iberian Peninsula. For Ecol Manag 84:219-229. https://doi.org/10.1016/0378-1127(96)03729-2

Aranda I, Gil L, Pardos JA (2000) Water relations and gas exchange in Fagus sylvatica L. and Quercus petraea (Mattuschka) Liebl. in a mixed stand at their southern limit of distribution in Europe. Trees 14:344-352. https://doi.org/10.1007/s004680050229

Aranda I, Gil L, Pardos JA (2005) Seasonal changes in apparent hydraulic conductance and their implications for water use of European beech (Fagus sylvatica L.) and sessile oak [Quercus petraea (Matt.) Liebl] in South Europe. Plant Ecol 179:155-167. https://doi.org/10.1007/ s11258-004-7007-1

Beguería S, Vicente-Serrano SM (2017) Calculation of the Standardised Precipitation-Evapotranspiration Index. http://sac.csic.es/spei

Biondi F, Qeadan F (2008) A theory-driven approach to tree-ring standardization: defining the biological trend from expected basal area increment. Tree-Ring Res 64:81-96. https://doi.org/10.3959/20086.1
Brang P, Spathelf P, Larsen JB, Bauhus J, Bonc ina A, Chauvin C, Drossler L, Garcia-Guemes C, Heiri C, Kerr G, Lexer MJ, Mason B, Mohren F, Muhlethaler U, Nocentini S, Svoboda M (2014) Suitability of close-to-nature silviculture for adapting temperate European forests to climate change. Forestry 87:492-503. https:// doi.org/10.1093/forestry/cpu018

Bréda N, Huc R, Granier A, Dreyer E (2006) Temperate forest trees and stands under severe drought: a review of ecophysiological responses, adaptation processes and long-term consequences. Ann For Sci 63:625-644. https://doi.org/10.1051/forest:2006042

Camarero JJ, Bigler C, Linares JC, Gil-Pelegrín E (2011) Synergistic effects of past historical logging and drought on the decline of Pyrenean silver fir forests. For Ecol Manag 262:759-769. https:// doi.org/10.1016/J.FORECO.2011.05.009

Camarero JJ, Gazol A, Sangüesa-Barreda G, Oliva J, Vicente-Serrano SM (2015) To die or not to die: early warnings of tree dieback in response to a severe drought. J Ecol 103:44-57. https://doi.org/10. $1111 / 1365-2745.12295$

Cavin L, Jump AS (2017) Highest drought sensitivity and lowest resistance to growth suppression are found in the range core of the tree Fagus sylvatica L. not the equatorial range edge. Glob Chang Biol 23:362-379. https://doi.org/10.1111/gcb.13366

Cescatti A, Piutti E (1998) Silvicultural alternatives, competition regime and sensitivity to climate in a European beech forest. For Ecol Manag 102:213-223. https://doi.org/10.1016/S0378-1127(97) 00163-1

Charru M, Seynave I, Hervé JC, Bertrand R, Bontemps JD (2017) Recent growth changes in Western European forests are driven by climate warming and structured across tree species climatic habitats. Ann For Sci 74:1-34. https://doi.org/10.1007/s13595-017-0626-1

Colangelo M, Camarero JJ, Battipaglia G, Borghetti M, de Micco V, Gentilesca T, Ripullone F (2017) A multi-proxy assessment of dieback causes in a Mediterranean oak species. Tree Physiol 37:617631. https://doi.org/10.1093/treephys/tpx002

Cressie N (1985) Fitting variogram models by weighted least squares. J Int Assoc Math Geol 17:563-586. https://doi.org/10.1007/ BF01032109

De Iaco S, Myers DE, Posa D (2002) Nonseparable space-time covariance models: some parametric families. Math Geol 34:23-42. https://doi.org/10.1023/A:1014075310344

del Río M, Schütze G, Pretzsch H (2014) Temporal variation of competition and facilitation in mixed species forests in Central Europe. Plant Biol 16:166-176. https://doi.org/10.1111/plb.12029

DGCONA (1998) Segundo Inventario Forestal Nacional. 1986-1996. Ministerio de Agricultura, Pesca y Alimentación, Madrid, Spain

Diaconu D, Kahle H-P, Spiecker H (2015) Tree- and stand-level thinning effects on growth of European beech (Fagus sylvatica L.) on a northeast- and a southwest-facing slope in southwest Germany. Forests 6:3256-3277. https://doi.org/10.3390/f6093256

Dittmar C, Fricke W, Elling W (2006) Impact of late frost events on radial growth of common beech (Fagus sylvatica L.) in Southern Germany. Eur J For Res 125:249-259. https://doi.org/10.1007/ s10342-005-0098-y

Dorado-Liñán I, Cañellas I, Valbuena-Carabaña M, Gil L, Gea-Izquierdo G (2017a) Coexistence in the Mediterranean-temperate transitional border: multi-century dynamics of a mixed old-growth forest under global change. Dendrochronologia 44:48-57. https://doi.org/10. 1016/J.DENDRO.2017.03.007

Dorado-Liñán I, Zorita E, Martínez-Sancho E, Gea-Izquierdo G, di Filippo A, Gutiérrez E, Levanic T, Piovesan G, Vacchiano G, Zang C, Zlatanov T, Menzel A (2017b) Large-scale atmospheric circulation enhances the Mediterranean east-west tree growth contrast at rear-edge deciduous forests. Agric For Meteorol 239:86-95. https://doi.org/10.1016/j.agrformet.2017.02.029

Dorado-Liñán I, Piovesan G, Martínez-Sancho E, Gea-Izquierdo G, Zang C, Cañellas I, Castagneri D, di Filippo A, Gutiérrez E, Ewald J, 
Fernández-de-Uña L, Hornstein D, Jantsch MC, Levanič T, Mellert KH, Vacchiano G, Zlatanov T, Menzel A (2019) Geographical adaptation prevails over species-specific determinism in trees' vulnerability to climate change at Mediterranean rear-edge forests. Glob Chang Biol 25:1296-1314. https://doi.org/10.1111/gcb.14544

Dormann CF, Elith J, Bacher S, Buchmann C, Carl G, Carré G, Marquéz JRG, Gruber B, Lafourcade B, Leitão PJ, Münkemüller T, McClean C, Osborne PE, Reineking B, Schröder B, Skidmore AK, Zurell D, Lautenbach S (2013) Collinearity: a review of methods to deal with it and a simulation study evaluating their performance. Ecography (Cop) 36:27-46. https://doi.org/10.1111/j.1600-0587.2012.07348.x

Fang Y (2011) Asymptotic equivalence between cross-validations and Akaike Information Criteria in mixed-effects models. J Data Sci 9: $15-21$

Fernández-de-Uña L, Cañellas I, Gea-Izquierdo G (2015) Stand competition determines how different tree species will cope with a warming climate. PLoS One 10:e0122255. https://doi.org/10.1371/ journal.pone. 0122255

Foster JR, Finley AO, D'Amato AW et al (2016) Predicting tree biomass growth in the temperate-boreal ecotone: Is tree size, age, competition, or climate response most important? Glob Chang Biol 22: 2138-2151. https://doi.org/10.1111/gcb.13208

Fritts HC (1976) Tree rings and climate. Laboratory of Tree-Ring Research, University of Arizona, Tucson

Gea-Izquierdo G, Viguera B, Cabrera M, Cañellas I (2014) Drought induced decline could portend widespread pine mortality at the xeric ecotone in managed Mediterranean pine-oak woodlands. For Ecol Manag 320:70-82. https://doi.org/10.1016/J.FORECO.2014.02. 025

Gil L, Náger JA, Aranda García I et al (2009) El Hayedo de Montejo: una gestión sostenible. Comunidad de Madrid, Madrid

Giorgi F, Lionello P (2008) Climate change projections for the Mediterranean region. Glob Planet Chang 63:90-104. https://doi. org/10.1016/J.GLOPLACHA.2007.09.005

Gómez C, Wulder MA, White JC, Montes F, Delgado JA (2012) Characterizing 25 years of change in the area, distribution, and carbon stock of Mediterranean pines in Central Spain. Int J Remote Sens 33:5546-5573. https://doi.org/10.1080/01431161.2012. 663115

Gómez-Aparicio L, García-Valdés R, Ruíz-Benito P, Zavala MA (2011) Disentangling the relative importance of climate, size and competition on tree growth in Iberian forests: Implications for forest management under global change. Glob Chang Biol 17:2400-2414. https://doi.org/10.1111/j.1365-2486.2011.02421.x

González de Andrés E, Camarero JJ, Blanco JA, Imbert JB, Lo YH, Sangüesa-Barreda G, Castillo FJ (2018) Tree-to-tree competition in mixed European beech-scots pine forests has different impacts on growth and water-use efficiency depending on site conditions. J Ecol 106:59-75. https://doi.org/10.1111/1365-2745.12813

Hampe A, Petit RJ (2005) Conserving biodiversity under climate change: the rear edge matters. Ecol Lett 8:461-467. https://doi.org/10.1111/ j.1461-0248.2005.00739.x

Harmer R (1994) Natural regeneration of broadleaved trees in Britain: II seed production and predation. Forestry 67:275-286. https://doi.org/ 10.1093/forestry/67.4.275-a

Hein S, Dhôte J-F (2006) Effect of species composition, stand density and site index on the basal area increment of oak trees (Quercus sp.) in mixed stands with beech (Fagus sylvatica L.) in northern France. Ann For Sci 63:457-467. https://doi.org/10.1051/forest:2006026

Hernández L, Camarero JJ, Gil-Peregrín E, Saz Sánchez MÁ, Cañellas I, Montes F (2019) Biotic factors and increasing aridity shape the altitudinal shifts of marginal Pyrenean silver fir populations in Europe. For Ecol Manag 432:558-567. https://doi.org/10.1016/J. FORECO.2018.09.037

Holmes RL (1997) The dendrochronology program library. In: GrissinoMayer HD, Holmes RL, Fritts HC (eds) The international tree-ring data bank program library Ver. 2.1 user's manual. Laboratory of Tree-Ring Research, University of Arizona, Tucson, pp 40-71

Holmes R, Adams RK, Fritts HC (1986) Tree-ring chronologies of western North America: California, eastern Oregon and northern Great Basin with procedures used in the chronology development work including users manuals for computer programs COFECHA and ARSTAN. Laboratory of Tree-Ring Research, University of Arizona, Tucson

Hosseini A, Hosseini SM, Linares JC (2018) Site factors and stand conditions associated with Persian oak decline in Zagros mountain forests. For Syst 26:e014. https://doi.org/10.5424/fs/2017263-11298

IPCC (2014) Climate change 2014: synthesis report. Contribution of working groups I, II and III to the fifth assessment report of the Intergovernmental Panel on Climate Change. Geneva, Switzerland

Jacob D, Petersen J, Eggert B, Alias A, Christensen OB, Bouwer LM, Braun A, Colette A, Déqué M, Georgievski G, Georgopoulou E, Gobiet A, Menut L, Nikulin G, Haensler A, Hempelmann N, Jones C, Keuler K, Kovats S, Kröner N, Kotlarski S, Kriegsmann A, Martin E, van Meijgaard E, Moseley C, Pfeifer S, Preuschmann S, Radermacher C, Radtke K, Rechid D, Rounsevell M, Samuelsson P, Somot S, Soussana JF, Teichmann C, Valentini R, Vautard R, Weber B, Yiou P (2014) EURO-CORDEX: new high-resolution climate change projections for European impact research. Reg Environ Chang 14:563-578. https://doi.org/10.1007/s10113-0130499-2

Jevšenak J, Levanič T (2018) dendroTools: R package for studying linear and nonlinear responses between tree-rings and daily environmental data. Dendrochronologia 48:32-39. https://doi.org/10.1016/j. dendro.2018.01.005

Liang H, Huang J-G, Ma Q, Li J, Wang Z, Guo X, Zhu H, Jiang S, Zhou P, Yu B, Luo D (2019) Contributions of competition and climate on radial growth of Pinus massoniana in subtropics of China. Agric For Meteorol 274:7-17. https://doi.org/10.1016/J.AGRFORMET.2019. 04.014

Linares JC, Camarero JJ, Carreira JA (2009) Interacting effects of changes in climate and forest cover on mortality and growth of the southernmost European fir forests. Glob Ecol Biogeogr 18:485-497. https://doi.org/10.1111/j.1466-8238.2009.00465.x

Linares JC, Camarero JJ, Carreira JA (2010) Competition modulates the adaptation capacity of forests to climatic stress: insights from recent growth decline and death in relict stands of the Mediterranean fir Abies pinsapo. J Ecol 98:592-603. https://doi.org/10.1111/j.13652745.2010.01645.x

Lloret F, Keeling EG, Sala A (2011) Components of tree resilience: effects of successive low-growth episodes in old ponderosa pine forests. Oikos 120:1909-1920. https://doi.org/10.1111/j.16000706.2011.19372.x

López Santalla A, Pardo Navarro F, Alonso Náger J, Gil Sánchez L (2003) El aprovechamiento tradicional del monte y sus efectos sobre la vegetación en el Hayedo de Montejo (Madrid). Cuad Soc Esp Cien For 16:109-114

Macias M, Andreu L, Bosch O, Camarero JJ, Gutiérrez E (2006) Increasing aridity is enhancing silver fir Abies alba Mill. water stress in its south-western distribution limit. Clim Chang 79:289-313. https://doi.org/10.1007/s10584-006-9071-0

Manso R, Morneau F, Ningre F, Fortin M (2015) Effect of climate and intra- and inter-specific competition on diameter increment in beech and oak stands. Forestry 88:540-551. https://doi.org/10.1093/ forestry/cpv020

Martín-Benito D, Kint V, del Río M et al (2011) Growth responses of West-Mediterranean Pinus nigra to climate change are modulated by competition and productivity: past trends and future perspectives. For Ecol Manag 262:1030-1040. https://doi.org/10.1016/J. FORECO.2011.05.038

Martinez del Castillo E, Prislan P, Gričar J, Gryc V, Merela M, Giagli K, de Luis M, Vavrčík H, Čufar K (2018) Challenges for growth of 
beech and co-occurring conifers in a changing climate context. Dendrochronologia 52:1-10. https://doi.org/10.1016/j.dendro. 2018.09.001

McLauchlan KK, Higuera PE, Miesel J et al (2020) Fire as a fundamental ecological process: research advances and frontiers. J Ecol 108: 2047-2069. https://doi.org/10.1111/1365-2745.13403

Michelot A, Simard S, Rathgeber C, Dufrene E, Damesin C (2012) Comparing the intra-annual wood formation of three European species (Fagus sylvatica, Quercus petraea and Pinus sylvestris) as related to leaf phenology and non-structural carbohydrate dynamics. Tree Physiol 32:1033-1045. https://doi.org/10.1093/treephys/ tps052

Millerón M, López de Heredia U, Lorenzo Z, Perea R, Dounavi A, Alonso J, Gil L, Nanos N (2012) Effect of canopy closure on pollen dispersal in a wind-pollinated species (Fagus sylvatica L.). Plant Ecol 213:1715-1728. https://doi.org/10.1007/s11258-012-0125-2

Millerón M, López de Heredia U, Lorenzo Z, Alonso J, Dounavi A, Gil L, Nanos N (2013) Assessment of spatial discordance of primary and effective seed dispersal of European beech ( Fagus sylvatica L.) by ecological and genetic methods. Mol Ecol 22:1531-1545. https:// doi.org/10.1111/mec. 12200

Monserud RA, Sterba H (1996) A basal area increment model for individual trees growing in even- and uneven-aged forest stands in Austria. For Ecol Manag 80:57-80. https://doi.org/10.1016/03781127(95)03638-5

Morales P, Hickler T, Rowell DP et al (2007) Changes in European ecosystem productivity and carbon balance driven by regional climate model output. Glob Chang Biol 13:108-122. https://doi.org/ 10.1111/j.1365-2486.2006.01289.x

Moreno-Fernández D, Hernández L, Sánchez-González M, Cañellas I, Montes F (2016) Space-time modeling of changes in the abundance and distribution of tree species. For Ecol Manag 372:206-216. https://doi.org/10.1016/J.FORECO.2016.04.024

Muffler L, Weigel R, Hacket-Pain AJ, Klisz M, Maaten E, Wilmking M, Kreyling J, Maaten-Theunissen M (2020) Lowest drought sensitivity and decreasing growth synchrony towards the dry distribution margin of European beech. J Biogeogr 47:1910-1921. https://doi. org/10.1111/jbi.13884

Munshi J (2016) Illusory statistical power in time series analysis. SSRN Electron J. https://doi.org/10.2139/ssrn.2878419

Nakagawa S, Schielzeth H (2013) A general and simple method for obtaining $R^{2}$ from generalized linear mixed-effects models. Methods Ecol Evol 4:133-142. https://doi.org/10.1111/j.2041210x.2012.00261.x

Nechita C, Macovei I, Popa I, Badea ON, Apostol EN, Eggertsson Ó (2019) Radial growth-based assessment of sites effects on pedunculate and greyish oak in southern Romania. Sci Total Environ 694: 133709. https://doi.org/10.1016/j.scitotenv.2019.133709

Neuman SP, Jacobson EA (1984) Analysis of nonintrinsic spatial variability by residual kriging with application to regional groundwater levels. J Int Assoc Math Geol 16:499-521. https://doi.org/10.1007/ BF01886329

Pardo F, Gil L (2005) The impact of traditional land use on woodlands: a case study in the Spanish Central System. J Hist Geogr 31:390-408. https://doi.org/10.1016/J.JHG.2004.11.002

Pardo F, Gil L, Pardos JA (1997) Field study of beech (Fagus sylvatica L.) and melojo oak (Quercus pyrenaica Willd) leaf litter decomposition in the centre of the Iberian Peninsula. Plant Soil 191:89-100. https://doi.org/10.1023/A:1004237305438

Pardo F, Gil L, Pardos JA (2004) Structure and composition of pole-stage stands developed in an ancient wood pasture in central Spain. Forestry 77:67-74. https://doi.org/10.1093/forestry/77.1.67

Penniston R, Lundberg A (2014) Forest expansion as explained by climate change and changes in land use: a study from Bergen, western Norway. Geogr Ann Ser A, Phys Geogr 96:n/a. https://doi.org/10. 1111/geoa. 12056
Pérez-de-Lis G, Olano JM, Rozas V, Rossi S, Vázquez-Ruiz RA, GarcíaGonzález I (2017) Environmental conditions and vascular cambium regulate carbon allocation to xylem growth in deciduous oaks. Funct Ecol 31:592-603. https://doi.org/10.1111/1365-2435.12789

Pflug EE, Buchmann N, Siegwolf RTW, Schaub M, Rigling A, Arend M (2018) Resilient leaf physiological response of European beech (Fagus sylvatica L.) to summer drought and drought release. Front. Plant Sci 9:187. https://doi.org/10.3389/fpls.2018.00187

Piovesan G, Biondi F, Di Filippo A et al (2008) Drought-driven growth reduction in old beech (Fagus sylvatica L.) forests of the central Apennines, Italy. Glob Chang Biol 14:1265-1281. https://doi.org/ 10.1111/j.1365-2486.2008.01570.x

Piutti E, Cescatti A (1997) A quantitative analysis of the interactions between climatic response and intraspecific competition in European beech. Can J For Res 27:277-284. https://doi.org/10. 1139/x96-176

Pretzsch H, Schütze G, Uhl E (2013) Resistance of European tree species to drought stress in mixed versus pure forests: evidence of stress release by inter-specific facilitation. Plant Biol 15:483-495. https:// doi.org/10.1111/j.1438-8677.2012.00670.x

Price B, Kaim D, Szwagrzyk M, Ostapowicz K, Kolecka N, Schmatz DR, Wypych A, Kozak J (2017) Legacies, socio-economic and biophysical processes and drivers: the case of future forest cover expansion in the Polish Carpathians and Swiss Alps. Reg Environ Chang 17: 2279-2291. https://doi.org/10.1007/s10113-016-1079-Z

Reyer C, Lasch-Born P, Suckow F, Gutsch M, Murawski A, Pilz T (2014) Projections of regional changes in forest net primary productivity for different tree species in Europe driven by climate change and carbon dioxide. Ann For Sci 71:211-225. https://doi.org/10. 1007/s13595-013-0306-8

Richards AE, Forrester DI, Bauhus J, Scherer-Lorenzen M (2010) The influence of mixed tree plantations on the nutrition of individual species: a review. Tree Physiol 30:1192-1208. https://doi.org/10. 1093/treephys/tpq035

Rodriguez-Calcerrada J, Atkin OK, Robson TM, Zaragoza-Castells J, Gil L, Aranda I (2010) Thermal acclimation of leaf dark respiration of beech seedlings experiencing summer drought in high and low light environments. Tree Physiol 30:214-224. https://doi.org/10.1093/ treephys/tpp104

Rodríguez-Calcerrada J, López R, Salomón R et al (2015) Stem $\mathrm{CO}_{2}$ efflux in six co-occurring tree species: underlying factors and ecological implications. Plant Cell Environ 38:1104-1115. https://doi. org $/ 10.1111 /$ pce. 12463

Rozas V (2001) Detecting the impact of climate and disturbances on treerings of Fagus sylvatica L. and Quercus robur L. in a lowland forest in Cantabria, Northern Spain. Ann For Sci 58:237-251. https://doi. org/10.1051/forest:2001123

Rozas V (2014) Individual-based approach as a useful tool to disentangle the relative importance of tree age, size and inter-tree competition in dendroclimatic studies. IForest 8:187-194. https://doi.org/10.3832/ ifor1249-007

Rozas V, Camarero JJ, Sangüesa-Barreda G, Souto M, García-González I (2015) Summer drought and ENSO-related cloudiness distinctly drive Fagus sylvatica growth near the species rear-edge in northern Spain. Agric For Meteorol 201:153-164. https://doi.org/10.1016/J. AGRFORMET.2014.11.012

Rubio-Cuadrado Á, Camarero JJ, Aspizua R, Sánchez-González M, Gil L, Montes F (2018a) Abiotic factors modulate post-drought growth resilience of Scots pine plantations and rear-edge Scots pine and oak forests. Dendrochronologia 51:54-65. https://doi.org/10.1016/j. dendro.2018.08.001

Rubio-Cuadrado Á, Camarero JJ, del Río M, Sánchez-González M, RuizPeinado R, Bravo-Oviedo A, Gil L, Montes F (2018b) Drought modifies tree competitiveness in an oak-beech temperate forest. For Ecol Manag 429:7-17. https://doi.org/10.1016/j.foreco.2018. 06.035 
Rubio-Cuadrado Á, Camarero JJ, del Río M, Sánchez-González M, RuizPeinado R, Bravo-Oviedo A, Gil L, Montes F (2018c) Long-term impacts of drought on growth and forest dynamics in a temperate beech-oak-birch forest. Agric For Meteorol 259:48-59. https://doi. org/10.1016/j.agrformet.2018.04.015

Rubio-Cuadrado Á, Camarero Martínez JJ, Gonzalez Gordaliza GJ, et al (2020) Datos de dendrocronología y competencia de El Hayedo de Montejo. V1. e-cienciaDatos.[Dataset]. https://doi.org/10.21950/ VEQWPI

Ruiz-Benito P, Lines ER, Gómez-Aparicio L, Zavala MA, Coomes DA (2013) Patterns and drivers of tree mortality in Iberian forests: climatic effects are modified by competition. PLoS One 8:e56843. https://doi.org/10.1371/JOURNAL.PONE.0056843

Sánchez de Dios R, Hernández L, Montes F, Sainz-Ollero H, Cañellas I (2016) Tracking the leading edge of Fagus sylvatica in NorthWestern Iberia: Holocene migration inertia, forest succession and recent global change. Perspect Plant Ecol Evol Syst 20:11-21. https://doi.org/10.1016/j.ppees.2016.03.001

Sánchez de Dios R, Gómez C, Aulló I et al (2020) Fagus sylvatica L. peripheral populations in the Mediterranean Iberian Peninsula: climatic or anthropic relicts? Ecosystems:1-16. https://doi.org/10. 1007/s10021-020-00513-8

Sánchez-Salguero R, Linares JC, Camarero JJ, Madrigal-González J, Hevia A, Sánchez-Miranda Á, Ballesteros-Cánovas JA, AlfaroSánchez R, García-Cervigón AI, Bigler C, Rigling A (2015) Disentangling the effects of competition and climate on individual tree growth: a retrospective and dynamic approach in Scots pine. For Ecol Manag 358:12-25. https://doi.org/10.1016/J.FORECO.2015. 08.034

Sánchez-Salguero R, Camarero JJ, Carrer M, Gutiérrez E, Alla AQ, Andreu-Hayles L, Hevia A, Koutavas A, Martínez-Sancho E, Nola P, Papadopoulos A, Pasho E, Toromani E, Carreira JA, Linares JC (2017) Climate extremes and predicted warming threaten Mediterranean Holocene firs forests refugia. Proc Natl Acad Sci 114:E10142-E10150. https://doi.org/10.1073/pnas.1708109114

Sarris D, Christodoulakis D, Körner C (2007) Recent decline in precipitation and tree growth in the eastern Mediterranean. Glob Chang Biol 13:1187-1200. https://doi.org/10.1111/j.1365-2486.2007. 01348.x

Sarris D, Christodoulakis D, Körner C (2011) Impact of recent climatic change on growth of low elevation eastern Mediterranean forest trees. Clim Chang 106:203-223. https://doi.org/10.1007/s10584010-9901-y

Schoolman EM, Mensing S, Piovesan G (2018) Land use and the human impact on the environment in medieval Italy. J Interdiscip Hist 49: 419-444. https://doi.org/10.1162/jinh_a_01303

Schweingruber FH, Eckstein D, Serre-Bachet F, Bräker OU (1990) Identification, presentation and interpretation of event years and pointer years in dendrochronology. Dendrochronologia 8:9-38

Seidling W, Ziche D, Beck W (2012) Climate responses and interrelations of stem increment and crown transparency in Norway spruce, Scots pine, and common beech. For Ecol Manag 284:196-204. https://doi.org/10.1016/j.foreco.2012.07.015

Serra-Maluquer X, Gazol A, Sangüesa-Barreda G, Sánchez-Salguero R, Rozas V, Colangelo M, Gutiérrez E, Camarero JJ (2019) Geographically structured growth decline of rear-edge Iberian
Fagus sylvatica forests after the 1980s shift toward a warmer climate. Ecosystems 22:1325-1337. https://doi.org/10.1007/s10021019-00339-Z

Speer JH (2012) Fundamentals of tree ring research. The University of Arizona Press, Tucson

Stadt KJ, Huston C, Coates KD, Feng Z, Dale MRT, Lieffers VJ (2007) Evaluation of competition and light estimation indices for predicting diameter growth in mature boreal mixed forests. Ann For Sci 64: 477-490. https://doi.org/10.1051/forest:2007025

Tegel W, Seim A, Hakelberg D, Hoffmann S, Panev M, Westphal T, Büntgen U (2014) A recent growth increase of European beech (Fagus sylvatica L.) at its Mediterranean distribution limit contradicts drought stress. Eur J For Res 133:61-71. https://doi.org/10. 1007/s10342-013-0737-7

Valbuena-Carabaña M, González-Martínez SC, Gil L (2008) Coppice forests and genetic diversity: a case study in Quercus pyrenaica Willd. from Central Spain. For Ecol Manag 254:225-232. https:// doi.org/10.1016/J.FORECO.2007.08.001

Valbuena-Carabaña M, de Heredia UL, Fuentes-Utrilla P, GonzálezDoncel I, Gil L (2010) Historical and recent changes in the Spanish forests: a socio-economic process. Rev Palaeobot Palynol 162:492-506. https://doi.org/10.1016/J.REVPALBO.2009.11.003

van der Maaten-Theunissen M, van der Maaten E, Bouriaud O (2015) pointRes: an R package to analyze pointer years and components of resilience. Dendrochronologia 35:34-38. https://doi.org/10.1016/J. DENDRO.2015.05.006

Vayreda J, Martinez-Vilalta J, Gracia M, Retana J (2012) Recent climate changes interact with stand structure and management to determine changes in tree carbon stocks in Spanish forests. Glob Chang Biol 18:1028-1041. https://doi.org/10.1111/j.1365-2486.2011.02606.x

Vicente-Serrano SM, Beguería S, López-Moreno JI, Angulo M, el Kenawy A (2010a) A new global $0.5^{\circ}$ gridded dataset (19012006) of a multiscalar drought index: comparison with current drought index datasets based on the Palmer Drought Severity Index. J Hydrometeorol 11:1033-1043. https://doi.org/10.1175/ 2010JHM1224.1

Vicente-Serrano SM, Beguería S, López-Moreno JI et al (2010b) A multiscalar drought index sensitive to global warming: the Standardized Precipitation Evapotranspiration Index. J Clim 23: 1696-1718. https://doi.org/10.1175/2009JCLI2909.1

Voelker SL, Muzika R-M, Guyette RP (2008) Individual tree and stand level influences on the growth, vigor, and decline of red oaks in the Ozarks. For Sci 54:8-20. https://doi.org/10.1093/forestscience/54.1. 8

Weber P, Bugmann H, Fonti P, Rigling A (2008) Using a retrospective dynamic competition index to reconstruct forest succession. For Ecol Manag 254:96-106. https://doi.org/10.1016/J.FORECO. 2007.07.031

Zuur AF, Ieno EN, Walker N, Saveliev AA, Smith GM (2009) Mixed effects models and extensions in ecology with R. Springer New York, New York

Publisher's note Springer Nature remains neutral with regard to jurisdictional claims in published maps and institutional affiliations. 